NBER WORKING PAPER SERIES

\title{
A STRUCTURAL APPROACH TO MARKET DEFINITION WITH AN APPLICATION TO THE HOSPITAL INDUSTRY
}

\author{
Martin Gaynor \\ Samuel A. Kleiner \\ William B. Vogt \\ Working Paper 16656 \\ http://www.nber.org/papers/w16656
}

\author{
NATIONAL BUREAU OF ECONOMIC RESEARCH \\ 1050 Massachusetts Avenue \\ Cambridge, MA 02138 \\ January 2011
}

Corresponding Author: skleiner@ cornell.edu. We are grateful to Cory Capps, Rein Halbersma, R. Forrest McCluer, Barry Harris and Misja Mikkers for their comments and suggestions and Rob Jones for his computing assistance. All errors and opinions are the sole responsibility of the authors. The views expressed herein are those of the authors and do not necessarily reflect the views of the National Bureau of Economic Research.

NBER working papers are circulated for discussion and comment purposes. They have not been peerreviewed or been subject to the review by the NBER Board of Directors that accompanies official NBER publications.

(C) 2011 by Martin Gaynor, Samuel A. Kleiner, and William B. Vogt. All rights reserved. Short sections of text, not to exceed two paragraphs, may be quoted without explicit permission provided that full credit, including $\odot$ notice, is given to the source. 
A Structural Approach to Market Definition With an Application to the Hospital Industry Martin Gaynor, Samuel A. Kleiner, and William B. Vogt

NBER Working Paper No. 16656

January 2011

JEL No. I11,K21,L1,L4

\begin{abstract}
$\underline{\text { ABSTRACT }}$
Market definition is essential to merger analysis. Because no standard approach to market definition exists, opposing parties in antitrust cases often disagree about the extent of the market. These differences have been particularly relevant in the hospital industry, where the courts have denied seven of eight merger challenges since 1994, due largely to disagreements over geographic market definition. We compare geographic markets produced using common ad hoc methodologies to a method that directly applies the "SSNIP test" to hospitals in California using a structural model. Our results suggest that previously employed methods overstate hospital demand elasticities by a factor of 2.4 to 3.4 and define larger markets than would be implied by the merger guidelines's hypothetical monopolist test. The use of these methods in differentiated product industries may lead to mistaken geographic market delineation, and was likely a contributing factor to the permissive legal environment for hospital mergers.
\end{abstract}

Martin Gaynor

Heinz College

Carnegie Mellon University

4800 Forbes Avenue, Room 241

Pittsburgh, PA 15213-3890

and NBER

mgaynor@cmu.edu

Samuel A. Kleiner

Cornell University

College of Human Ecology

108 Martha Van Rensselaer Hall

Ithaca, NY 14853

and NBER

skleiner@cornell.edu
William B. Vogt

513 Brooks Hall

Department of Economics

Terry College of Business

University of Georgia

Athens, GA 30602

william.b.vogt@gmail.com 


\section{Introduction}

Market definition is pivotal to the antitrust process and a key part of merger analysis (Baker, 2007). The assessment of the potential competitive effects of a merger or acquisition rest so heavily on the definition of a relevant antitrust market that Robert Pitofsky, the former chairman of the Federal Trade Commission (FTC), noted that "antitrust practitioners have long known that the most important single issue in most enforcement actions—-because so much depends on it—is market definition." (Pitofsky, 1990, p. 1807). While there is an approximate consensus about how market definition should be done in principle (Baker, 2007), there is wide variation in how it is implemented in practice. A number of ad hoc methods have been used which, as we show, do not correspond well to the agreed upon concept of an antitrust market. Although these ad hoc methods have been widely criticized, to our knowledge they have not been previously compared to empirical antitrust markets that are consistent with economic theory.

It is clear that an antitrust market should be the set of products and locations that exercise a significant competitive constraint on each other (Motta, 2004). The U.S. antitrust authorities introduced the "SSNIP" test as a method for delineating markets (Federal Trade Commission and U.S. Department of Justice, 1982), and this approach has been adopted by competition authorities worldwide. The Small but Significant and Nontransitory Increase in Price (SSNIP) test begins by defining a narrow market and asking whether a hypothetical monopolist in the defined market could profitably implement a SSNIP (usually a 5 percent price increase for 1 year). If sufficient numbers of consumers are likely to switch to alternative products so as to make the price increase unprofitable, 
then the firm or cartel lacks the power to raise price. The relevant market therefore needs to be expanded. The next closest substitute is added and the process is repeated until the point is reached where a hypothetical cartel or monopolist could profitably impose a 5\% price increase. The set of products/locations so defined constitutes the relevant market.

While the conceptual exercise prescribed by the SSNIP is straightforward, implementation in practice is not. This is in part due to data limitations, and in part due to analysts' failure to utilize econometric analysis. If one has reliable estimates of demand in hand, the SSNIP test can be implemented in a clear-cut way that is consistent with the conceptual exercise. In the past, data limitations precluded demand estimation. In addition, modern econometric methods were not brought to antitrust until approximately 20 years ago (Scheffman and Spiller, 1987). As a consequence, ad hoc methods of market definition were developed that did not require either extensive data or econometric methods (Elzinga and Hogarty, 1973, 1978; Harris and Simons, 1989).

These simple quantitative approaches to market definition have been widely used in antitrust analysis, yet have been criticized for their static nature, simplifying assumptions and internal inconsistencies that have the potential to affect the conclusions drawn from the use of these methods (Baker, 2007; Capps et al., 2002; Danger and Frech, 2001; Frech et al., 2004; Katz and Shapiro, 2003; Langenfeld and Li, 2001; Varkevisser et al., 2008; Werden, 1981, 1990).

The use of such ad hoc market definition methods has been particularly influential for antitrust decisions in the hospital industry, where 1,425 mergers and acquisitions were successfully consummated between 1994 and 2009. ${ }^{1}$ These mergers have resulted in

\footnotetext{
${ }^{1}$ Kaiser Family Foundation http://www.kff.org/insurance/7031/print-sec5.cfm (accessed July 16, 2010) and "Deals and Dealmakers: The Health Care M\&A Year in Review" Norwalk, CT: Irving Levin Associates,
} 
increases in the price of inpatient care (Keeler et al., 1999; Vita and Sacher, 2001; Capps et al., 2003; Gaynor \& Vogt, 2003; Dafny, 2009), no measurable increase in the quality of care (Hamilton and Ho, 2000) ${ }^{2}$ and an estimated loss of $\$ 42$ billion in consumer welfare (Town et al., 2005). ${ }^{3}$ While the hospital industry has seen more merger litigation in recent years than any other industry, ${ }^{4}$ the courts have denied all but one government request to block hospital mergers since $1994,{ }^{5}$ due largely to the inability of the antitrust authorities to convincingly define a geographic market that supports their case. ${ }^{6}$ In the eight cases brought to the courts since 1994, the primary reason given for denying the government's request in six of these cases centered on the markets delineation. ${ }^{7}$

This paper introduces a new method for market definition using a fully specified structural model of consumer demand and firm behavior. The exercise prescribed by the SSNIP can be performed exactly by using such a model. The use of these models has

Inc., $15^{\text {th }}$ Edition, 2010, $14^{\text {th }}$ Edition, 2009, $13^{\text {th }}$ Edition, 2008, $12^{\text {th }}$ Edition, 2007, http://www.levinassociates.com/compallconfirm?sid=6050 (accessed July 16, 2010).

${ }^{2}$ The Federal Trade Commission produced evidence in the Evanston Northwestern case that a hospital merger had led to increased prices without any corresponding increase in quality (see Majoras, 2007).

${ }^{3}$ See Town and Vogt (2006) for a recent survey on the effects of hospital consolidation.

${ }^{4}$ Health Care Mergers and Acquisitions Handbook, Section of Antitrust Law (American Bar Association, 2003) p. 1

${ }^{5}$ Evanston Northwestern Healthcare was decided in favor of the FTC in 2007. This case marked the first time the FTC retrospectively challenged a fully consummated hospital merger .Although the case was decided in favor of the FTC, no divestiture was mandated for the merging parties.

${ }^{6}$ Product market definition has not been an issue in hospital merger cases, therefore all of the attention has been focused on geographic markets.

${ }^{7}$ The eight cases brought since 1994 are Ukiah [In re Adventist Health System/West and Ukiah Adventist Hospital, 117 F.T.C. 224 (1994)], Joplin [FTC v. Freeman Hospital (1995, 911 F. Supp. 1213)], Dubuque [United States of America v. Mercy Health Services and Finley Tri-States Health Group, Inc., 902 F.Supp. 968 (1995)], Grand Rapids [Federal Trade Commission v. Butterworth Health Corporation and Blodgett Memorial Medical Center, 946 F. Supp. 1285 (1996)], Long Island [United States of America v. Long Island Jewish Medical Center and North Shore Health System, Inc., 983 F. Supp. 121 (1997)], Poplar Bluff [Federal Trade Commission v. Tenet Healthcare Corporation, 17 F. Supp. 2d 937 (1998)], Sutter [California v. Sutter Health Sys., 84 F. Supp. 2d 1057 (N.D. Cal.), aff'd mem., 2000-1 Trade Cas. (CCH) U 87,665 (9th Cir. 2000), revised, 130 F. Supp. 2d 1109 (N.D. Cal. 2001)] and Evanston [In the Matter of Evanston Northwestern Healthcare Corporation and ENH Medical Group, Inc., Initial Decision, Oct. 20, 2005, Docket No. 9315, available at http://www.ftc.gov/os/adjpro/d9315/ 051020initialdecision.pdf.]. All but U.S. v. Long Island Jewish Med. Ctr and Evanston Northwestern Health Care were lost due to failure to define a geographic market. Also, one of the cases was brought by state antitrust enforcers without either Agency's involvement. See Sutter Health Sys., 84 F. Supp. 2d 1057. 
been promoted in the past decade as a theoretically superior approach to merger analysis in differentiated product industries, (e.g., Motta, 2004; Baker, 2007; Geroski and Griffith, 2004; van Reenen, 2004; Ivaldi and Lörincz, 2009) however, such an approach has not been commonly employed in antitrust analysis. Consequently little is known about the differences in markets produced by these methods relative to methods used in actual cases. We apply this method to the hospital industry and compare the markets implied by this model to those produced by the ad hoc techniques that have been used in hospital merger cases. We seek to better understand the extent to which currently employed methods of market definition define markets that are consistent with the criteria for merger analysis described in the merger guidelines.

Our results suggest that the market definition techniques that have been used in antitrust enforcement of hospital mergers by and large incorrectly define (geographic) markets as specified by the merger guidelines' hypothetical monopolist test. Our analysis of a large subset of hospitals in the state of California using 1995 data suggests that markets implied by previously employed quantitative market definition methods are, in the majority of cases, substantially larger than those that would be implied by a method rooted in the principles set forth in the merger guidelines. Finally, our examination of mergers in San Diego provides an illustration of the differences in implied market concentration in a localized region of the state, and enables comparison of our approach to an alternative market definition method for hospitals developed by Capps et al. (2003).

Our paper proceeds as follows. Part I provides background on the merger guidelines and their application in the hospital industry. Part II discusses quantitative approaches to market definition. Part III outlines our use of a structural model to define 
geographic markets. Part IV details the simulation methods used for our comparison methodologies, while Part V describes our data. Part VI presents our main results. Part VII concludes.

\section{The Merger Guidelines and Market Definition}

\section{The Merger Guidelines}

The merger guidelines are a collaborative effort by the FTC and DOJ outlining the enforcement policy of the agencies concerning horizontal acquisitions and mergers subject to section 7 of the Clayton Act, section 1 of the Sherman Act, or section 5 of the FTC Act. ${ }^{8}$ They are considered to be the foremost articulation of the government's policy regarding enforcement standards for horizontal mergers (Werden, 1997). Their purpose is to convey the analytical framework by which the government is to go about determining the extent to which a merger is likely to lessen competition.

Though the first guidelines were released in 1968 and modified as recently as 2010, the thrust of the criteria for market definition was pioneered largely in the 1982 version. ${ }^{9}$ The approach to market definition in the 1982 guidelines focused on the central enforcement-related question of whether a merger would result in a price increase through the use of the "SSNIP" criterion. In the SSNIP criterion, an antitrust market is defined as a group of products and a geographic area in which a hypothetical profitmaximizing firm, not subject to price regulation, that was the only present and future seller of those products in that area would impose a "small but significant and non-

\footnotetext{
${ }^{8}$ Mergers subject to section 7 are prohibited if their effect "may be substantially to lessen competition, or to tend to create a monopoly." Mergers subject to section 1 are prohibited if they constitute a "contract, combination or conspiracy in restraint of trade." Mergers are subject to section 5 if they constitute an "unfair method of competition."

${ }^{9}$ The FTC joined the DOJ in releasing joint guidelines beginning in 1992.
} 
transitory increase in price" (SSNIP) above all prevailing or likely future levels holding constant the terms of sale for all products produced elsewhere. As a general matter, it defined a price increase as significant if it was at least $5 \%$ and lasted for one year. ${ }^{10}$ The general idea in this process is to find the smallest group of products or firms for which there are no close substitutes, thus allowing such a hypothetical monopolist to exert market power. ${ }^{11}$

The development of this concept was notable in that the economic reasoning was comprehensible to both attorneys and economists, and the methodology was operable. Though economists and attorneys still differ on the implementation aspect of market definition analysis, the basis for these disagreements is typically methodological rather than the fundamental theoretical question of what defines a market (Scheffman et al., 2002). To this day the SSNIP criterion continues to be the standard by which courts define antitrust markets.

The determination of market boundaries using the SSNIP test provides the basis on which any subsequent steps rest when evaluating a merger. As Miles (2005) details,

\footnotetext{
${ }^{10}$ This was later refined in 1984 to ensure that $5 \%$ was not a rule, but $5 \%$ has nonetheless remained a standard utilized in hospital merger cases by the courts. This was indicated in the Sutter case, as the court requires a basis for deviating from this prescribed 5\% figure. See California v. Sutter Health Sys., 84 F. Supp. 2d 1057 (N.D. Cal.), aff'd mem., 2000-1 Trade Cas. (CCH) U 87,665 (9th Cir. 2000), revised, 130 F. Supp. 2d 1109 (N.D. Cal. 2001).

${ }^{11}$ It should be noted that although the SSNIP test mandates that other prices be held constant, the assumption of Bertrand competition assumes that reaction functions of other firms are upward sloping in the prices of all other firms, and thus other firms would raise prices in reaction to the increase in price by a firm. For this reason, the sizes SSNIP estimates of geographic markets are most likely an upper bound. This is because upward sloping reaction functions for competitors (and thus higher prices) would induce less substitution away from the hospitals included in the SSNIP test, and thus would require a smaller number of coordinated price increases in order to increase profit. For an alternative approach that asks whether the candidates in the market would increase prices by at least 5\% in equilibrium, see Ivaldi and Lörincz (2009).
} 
the court is required to follow a sequence of steps in determining the legality of a merger consisting of ${ }^{12}$ :

1. Definition of the relevant product market.

2. Definition of the relevant geographic market.

3. Identification of the competitors in the market defined from steps (1) and (2).

4. Calculation of market shares and Herfindahl-Hirschmann Index (HHI) of the competitors in the market.

5. Calculation of merging firms' post-merger market share and the level of post-merger HHI. If this is too high, the merger is determined unlawful.

6. Consideration of other factors that indicate that the merger is unlikely to have anticompetitive effects, such as ease of entry, ownership status, excess capacity and efficiency gains.

The first two steps involved in merger analysis are pivotal to the process in each subsequent step. The inclusion of many products will understate market concentration, while failure to include relevant products will overstate concentration. Likewise, the delineation of geographic markets is fundamental to the determination of the degree of market power. The inclusion of an inappropriately large number of firms will overstate the degree of competition, while failure to incorporate all firms involved will understate the prevailing competitive environment.

Once the market boundaries have been set, the merger guidelines specify levels and changes in the HHI which serve as a guide as to when mergers are likely to be anticompetitive. ${ }^{13}$ According to the 2010 guidelines, markets with a post-merger HHI below

\footnotetext{
${ }^{12}$ The current (2010) guidelines offer more flexibility than in the past, in that "The Agencies' analysis need not start with market definition.....although evaluation of competitive alternatives available to customers is always necessary at some point in the analysis." (FTC/DOJ, 2010, p. 7)

${ }^{13}$ Because the thresholds set by the guidelines are intended to be a reference point, the FTC has been flexible in their enforcement of mergers conforming to these exact HHI thresholds. See Merger Challenges
} 
1,500 are said to be unconcentrated and are thus unlikely to have adverse competitive effects. Markets with post-merger HHIs between 1,500 and 2,500 are regarded as moderately concentrated and are likely to warrant scrutiny only if a merger will result in an increase in the HHI of more than 100. Mergers resulting in a post-merger HHI of above 2,500 are regarded as resulting in markets that are highly concentrated and thus mergers producing an increase in $\mathrm{HHI}$ of between 100 and 200 are presumed to raise significant competitive concerns, with increases of 200 points or more deemed likely to enhance market power.

\section{Application of the Merger Guidelines to Hospital Care}

In the case of hospital care, the relevant product market has not been an issue of contention in merger cases. The generally accepted product market definition has been to "cluster" products, leading to a typical product market definition of "general acute care hospital services." ${ }^{, 14}$ In only one of the last eight cases brought by the government has failure to convincingly define a product market been a deciding factor in a hospital merger case. ${ }^{15}$

The inability to convincingly define geographic markets for hospital care has, however, been the primary determining factor in six of the government's seven consecutive unsuccessful merger challenges between 1994 and 1999. Table 1 presents a

Data, Fiscal Years 1999-2003, Issued by the Federal Trade Commission and the U.S. Department of Justice at http://www.ftc.gov/os/2003/12/mdp.pdf

${ }^{14}$ Health Care Mergers and Acquisitions Handbook, Section of Antitrust Law (American Bar Association, 2003), p. 30

${ }^{15}$ See United States of America v. Long Island Jewish Medical Center and North Shore Health System, Inc., 983 F. Supp. 121 (1997). 
list of the most recent cases challenged by the government, as well as the size of the geographic markets and level of concentration in each market. ${ }^{16}$

\section{Quantitative Approaches to Geographic Market Definition}

As discussed above, market definition is pivotal to the antitrust process. Failure to correctly define a market may have serious consequences in antitrust cases. However, because the merger guidelines prescribe their methodology through a thought experiment rather than a concrete methodology, there is no uniform approach for defining these markets. As a result, numerous quantitative approaches have been suggested and applied across many industries including beverages, software, hospitals and supermarkets. These include approaches based on product shipments, methodologies incorporating econometric methods and merger simulation, and analysis of consummated mergers. ${ }^{17}$ Since we are using the hospital industry as our example, and since market definition issues in this industry have revolved around geographic, rather than product markets, our discussion in what follows will focus on geographic markets. It should be understood, however, that the methodological issues are essentially the same regardless of whether the focus is on product or geographic markets. ${ }^{18}$

\section{Shipments-Based Approaches}

\footnotetext{
${ }^{16}$ Only a fraction of the merger activity that has occurred has been challenged due to the issuance of the Statements of Antitrust Enforcement Policy in Health Care which stipulated that mergers involving hospitals with (1) less than 100 licensed beds, (2) less than 40 daily patients over the past 3 years, (3) a merger that has been in existence for more than 5 years would not be challenged (see http://www.ftc.gov/reports/hlth3s.htm).

${ }^{17}$ Although market definition cases rely upon quantitative methods as a basis for merger evaluation, these cases often use factual qualitative evidence as well, such as testimony from buyers of the relevant product. ${ }^{18}$ Once can think of geographic location as a product attribute, in which case there's no real difference between product and geographic markets.
} 
Shipments-based approaches have been commonly employed for geographic market definition analysis in industries such as beer, ${ }^{19}$ photographic film ${ }^{20}$ and software, ${ }^{21}$ and are, to the best of our knowledge, the only quantitative approaches employed in hospital merger cases. The two methodologies most heavily utilized, referred to as Elzinga-Hogarty and Critical Loss Analysis, rely on discharge (shipments) data which are usually available from the hospitals themselves or from state reporting agencies. Because of their utilization in the vast majority of hospital merger cases, we focus mainly on these approaches in our analysis, as our aim is to examine market definition methodology as it has been utilized in practice. Table 2 lists the market definition methods used in actual hospital merger cases.

\section{Elzinga-Hogarty}

The Elzinga-Hogarty method, (Elzinga and Hogarty, 1973, 1978) uses shipments information consisting of origin and destination data for delineating a market. Although not originally developed for use in the hospital industry, as Table 2 indicates, it has been utilized extensively in hospital merger cases. The Elzinga-Hogarty method determines that a geographic area constitutes a market if that area satisfies a joint ratio of import and export thresholds. The simultaneous satisfaction of these thresholds is evidence of the self-sufficiency of the area for both demand and supply, and is thus a geographic market. The method argues that if an area imports little of a particular product, it can be deemed a market from a demand perspective. By similar logic, Elzinga and Hogarty argue that if an

\footnotetext{
${ }^{19}$ United States v. Pabst Brewing Co., (1966)

${ }^{20}$ United States v. Eastman Kodak Co. (1995)

${ }^{21}$ United States v. Oracle Corp., (2004)
} 
area exports little of a particular product, it can be deemed a market from a supply perspective.

While Elzinga-Hogarty has frequently been acknowledged by the courts as an acceptable method by which to define geographic markets, there are a number of criticisms regarding the potential shortcomings of geographic markets defined using this methodology, with particular attention devoted to its limitations for defining hospital markets. ${ }^{22}$ The first centers on heterogeneity by geography in quality or service. This issue is particularly relevant in high-service, tertiary care urban hospitals which draw large inflows of patients from rural areas. If a sufficient number of rural patients obtain care at the urban hospitals, the Elzinga-Hogarty test could conclude that the urban and rural areas are in the same geographic market, even though the price of care in the rural region does not constrain the market power of the urban hospitals. As Werden (1990) indicates, this scenario leads to markets that are larger than would be reasonable given the hypothetical monopolist principle put forth in the merger guidelines.

Alternatively, the use of shipments data can underestimate the size of markets. As Werden (1981) illustrates, two firms may be close substitutes for each other but have no cross shipments between the regions in which they are located (due to consumers optimizing based on transportation costs). In this case Elzinga-Hogarty would erroneously conclude that each firm and its corresponding region constitute a market, despite the competitive constraints present due to their high cross price elasticities. Other critical assessments of the methodology's implications for behavior focus on its static nature which makes consumer behavioral assumptions based on the pre-merger

\footnotetext{
${ }^{22}$ In the most recent hospital merger case (In the Matter of Evanston Northwestern Healthcare Corporation, Docket No. 9315, FTC August 2007) Elzinga himself testified that the method is not appropriate for hospital market definition.
} 
rather than post-merger terms of sale, and the "silent majority" criticism of Capps et al. (2001) which implicitly assumes that if some patients are willing to travel to a more distant hospital to escape a price increase by the merging hospitals, other patients will do so as well. ${ }^{23}$

\section{Critical Loss Analysis}

Critical Loss analysis (Harris and Simons, 1989) has been widely employed in merger analysis since its introduction in 1989 (Epstein and Rubinfeld, 2004). It seeks to directly answer the question posed by the merger guidelines regarding the smallest set of hospitals that would have to be included in the market to make a hypothetical price increase of 5\% profitable. Although it has been used less frequently than the ElzingaHogarty methodology, Critical Loss has played an important role in determining geographic markets in industries such as chewing tobacco ${ }^{24}$ and supermarkets, ${ }^{25}$ and in hospital cases such as the Dubuque, Poplar Bluff and Sutter cases detailed in Table 2. In addition, in the Poplar Bluff case mentioned above, the circuit court gave substantial weight to the defendant's Critical Loss analysis in its reversal of the district court's initial ruling (Langenfeld and $\mathrm{Li}, 2001$ ).

The Critical Loss test proceeds in three steps. For a given set of firms, the first step is to determine, for a given price increase, the percentage reduction in demand that would render such a price increase unprofitable. This percentage reduction is a function

\footnotetext{
${ }^{23}$ For a summary of the arguments and evidence against the use of shipments based methods in the context of a recent case, see "Brief of Health Care and Industrial Organization Economists as Amici Curia in Support of Petitioners," Little Rock Cardiology Clinic PA v. Baptist Health, No. 09-1183, in the Supreme Court of the United States. http://www.scotusblog.com/wp-content/uploads/2010/06/09-1183 Amicusbrief-of-the-Health-Care-and-Industrial-Organization-Economists.pdf (accessed August 13, 2010).

${ }^{24}$ FTC v. Swedish Match North America Inc., and National Tobacco Company, LP.

${ }^{25}$ FTC v. Whole Foods Mkt., Inc. and Wild Oats Mkt., Inc.
} 
of the proposed price increase (typically fixed at 5\%) and the gross margin of the firm. For a firm with high margins, the loss of relatively few consumers will significantly impact profitability, while low margin firms would need to lose fewer customers in order to impose the same impact on profitability. The second step involves calculating the actual percentage of sales that a firm would lose were they to increase their price by a given percentage. This is called the estimated loss. The third step entails comparing the Critical Loss with the estimated loss. If the estimated loss is greater than the Critical Loss, this area does not constitute a market as defined by the SSNIP test. ${ }^{26}$ The market is then expanded to include firms that are viewed as the next closest substitutes for the group of hospitals in question.

While the principles of Critical Loss rest upon sound economic reasoning, in practice the implementation of Critical Loss has been subject to a number of criticisms. One criticism concerns the classification of accounting cost data used for the determination of the contribution margin, as the use of such data to calculate the contribution margin allows for discretion in the classification of fixed versus variable costs. An incentive exists for merging parties to classify a large portion of their costs as fixed, since such classification reduces the scope of costs that can be determined as variable, thus resulting in the determination of a high contribution margin and large Critical Loss markets (Langenfeld and Li, 2001).

The implementation methods used in the determination of the estimated loss have also been subject to criticism, particularly as they have been employed in hospital merger cases. This is because in practice, determination of the estimated loss in hospital merger

\footnotetext{
${ }^{26}$ Health Care Mergers and Acquisitions Handbook, Section of Antitrust Law (American Bar Association, 2003) p. 52-54
} 
cases has entailed examining zip codes in which a significant percentage (e.g. $20 \%$ or more) of patients already use other hospitals. It is then argued that given a price increase, a significant number of patients in these zip codes would switch to an alternative hospital and make such an increase unprofitable. Such claims are, however, disputed since the high contribution margins claimed by analysts also imply that the actual loss sustained by a firm would be small. This is because the presence of a large contribution margin implies a low elasticity of demand and consequently, a small actual loss (Katz and Shapiro, 2003; Danger and Frech, 2001). Furthermore, a paper by Simpson (2001) argues that in areas deemed contestable (presumably indicating a high elasticity of demand), price increases at nearby hospitals in actuality induce very small numbers of patients to switch, thus indicating that demand is in fact less elastic in these contestable zip codes than has been put forward in hospital merger cases.

\section{Market Definition Using a Structural Model}

\section{Using the Structural Model for Market Definition}

In what follows, we employ a structural model of market competition to implement the SSNIP test method to define hospital markets in California. We then go on to compare the markets obtained via the SSNIP test with those via the methods that have been commonly employed in hospital merger cases (Elzinga-Hogarty and Critical Loss). 
The structural model estimates demand and supply relation parameters and builds on the work of Baker and Bresnahan (1985), Scheffman and Spiller (1987), and Froeb and Werden (2000). We employ a model based on Berry, Levinsohn and Pakes's (2004) model of differentiated product oligopoly and adapted for use in the hospital industry by Gaynor and Vogt (2003). The model is well suited to the SSNIP criteria in that it is a fully specified model of price and quantity determination and it allows for the calculation of own-price and cross-price elasticities for each hospital in the data. In addition, it allows for the determination of an initial equilibrium price and quantity for the market, thus allowing for direct implementation of the thought experiment characterized by the merger guidelines.

This structural model of differentiated product oligopoly models demand at the level of an individual consumer using discrete choice techniques and micro data on individuals. This allows demographic characteristics at the level of individual consumers to explain hospital choice. In addition, its use of multinomial logit demand implies that the use of the model for merger predictions will result in lower post-merger prices (and thus larger antitrust markets) than would be produced by alternative specifications (Crooke et al., 1999). While this section presents the basic constructs of the model, for a full exposition, including parameter estimates, see Gaynor and Vogt (2003).

With a choice set of $j(\mathrm{j}=1, \ldots . . \mathrm{J})$ hospitals, the utility of consumer $i(=1, \ldots, \mathrm{N})$ is assumed to be of the form:

$$
U_{i j}=-\alpha_{p} p_{j}-p_{j} X_{i j}^{p} \alpha+X_{i j} \beta+X_{j} \gamma+\xi_{j}+\epsilon_{i j}
$$

where $p_{j}$ is the hospital price, $\alpha_{p}$ is the marginal utility of income, $X$ are observable consumer characteristics, observable hospital characteristics and their interactions, $X^{p}$ are 
consumer and hospital characteristics interacted with price and $\xi_{j}$ are unobservable hospital characteristics. Assuming that $\epsilon_{i j}$ is an i.i.d. Weibull random variable, the probability that consumer $i$ attends hospital $j$ can be written as:

$$
P_{i \rightarrow j}=\frac{\exp \left(-\alpha_{p} p_{j}+\cdots+\xi_{j}\right)}{\sum_{k=1}^{J} \exp \left(-\alpha_{p} p_{k}+\cdots+\xi_{k}\right)}
$$

and the demand faced by hospital $j$ charging price $p_{j}$ can be written as:

$$
Q_{j}=\sum_{i=1}^{N} q_{i} \times P_{i \rightarrow j}
$$

where $q_{i}$ is the quantity of hospital goods consumed by consumer $i$.

Because equation (1) contains an unobservable term $\left(\xi_{j}\right)$ that is correlated with price, a set of hospital fixed effects are used to absorb this source of endogeneity, as proposed by Berry, Levinsohn and Pakes (2004). Since the use of this fixed effect obfuscates identification of $\alpha_{p}$, an additional regression of these hospital fixed effects on hospital price and other observable hospital characteristics is used to recover this parameter. Because price is also endogenous in this additional regression, exogenous wages and predicted quantity (using only geographic distribution and exogenous consumer characteristics) are used as instruments for price, thus enabling recovery of $\alpha_{p}$, the marginal utility of income. 
In this model, firms are assumed to maximize profits à la Bertrand. ${ }^{27}$ Multi-plant firms (called multihospital systems) are also common in this industry, necessitating a model which accounts for substitution among plants and the coordination of pricing. Letting $\theta$ represent a $J \times J$ matrix with $\theta_{\mathrm{jk}}=1$ if hospitals $j$ and $k$ have the same owner and $\theta_{\mathrm{jk}}=0$ otherwise, the familiar Bertrand pricing equation used in the model is of the form:

$$
p=M C-\left[\Theta \otimes\left[\frac{\partial \mathrm{Q}}{\partial \mathrm{p}}\right]\right]^{-1} Q
$$

where $[\partial Q / \partial p]$ is the $J \times J$ demand derivative matrix and $\otimes$ denotes an element-byelement Hadamard matrix multiplication operator.

Of note for this model is that it allows for observed consumer heterogeneity via varying distances from consumers to hospitals and thus does not exhibit independence of irrelevant alternatives or the restrictive substitution patterns of the logit (Train, 2003). Using the estimates obtained from this model, own-price and cross-price elasticities can be calculated for each hospital in the dataset using the formulas:

$$
\begin{aligned}
& \frac{\partial Q_{j}}{\partial p_{j}}=\sum_{i=1}^{N} q_{i} P_{i \rightarrow j}\left(1-P_{i \rightarrow j}\right)\left(-\alpha-X_{i j}^{p} \alpha_{p}\right) \\
& \frac{\partial Q_{j}}{\partial p_{k}}=\sum_{i=1}^{N} q_{i} P_{i \rightarrow j} P_{i \rightarrow k}\left(\alpha+X_{i j}^{p} \alpha_{p}\right)
\end{aligned}
$$

where (5) corresponds to the calculation of the own-price, and (6) to the cross-price elasticity.

\footnotetext{
${ }^{27}$ Not-for-profit firms are common in this industry. Not-for-profit hospitals are assumed to value output (e.g., community service, access to care). This makes not-for-profits, in essence, like for-profits with lower marginal costs. The econometric model allows for marginal cost (and demand) differences between forprofits and not-for-profits.
} 
We present a summary of the key model characteristics in Table $3{ }^{28}$ Hospitals face a downward sloping demand curve, with average own-price elasticity of -4.57 and an average price of $\$ 4,681$ for a unit of care. Additionally, as the average cross-price elasticities in the bottom of Table 3 show, hospitals physically close to one another have higher cross-price elasticities than do hospitals far apart. For example, the average crossprice elasticity between a given hospital and its most proximate competitor (measured by distance) is calculated as 0.60 , while the cross-price elasticity with the fifth-closest competitor is one-third of this magnitude. This implies that markets for hospital care are largely local.

\section{Adapting the Structural Model for SSNIP Market Definition}

In order to define geographic markets that conform as closely as possible to the Merger Guidelines using the structural model, we define the SSNIP test for a given hospital as the smallest set of hospitals (inclusive of the hospitals for which we are attempting to define a SSNIP market) for which a given price increase would be profitable, holding constant price at all other hospitals. While a formal definition of our SSNIP markets is included in Appendix B, intuitively, the SSNIP criterion states that for a given hospital, $\mathrm{j}$, a SSNIP market is the smallest set of hospitals for which an increase in price at this set of hospitals (including hospital $\mathrm{j}$ ) would increase the collective profits in the systems of which these hospitals are members. This approach allows for the definition of geographic markets that take into account system membership, making it consistent with the current (2010) revision of the merger guidelines in its explicit

\footnotetext{
${ }^{28}$ All coefficient estimates are available at http://www.rje.org/abstracts/abstracts/2003/rje.winter03.gaynor.pdf
} 
treatment of firms that own multiple plants in the same geographic area. ${ }^{29}$ To illustrate the criterion, consider 4 hospitals, A, B, C and D, and let A and B be members of the same hospital system. Suppose hospitals A and C act as a "hypothetical monopolist" and engage in a coordinated price increase of 5\% (holding the terms of sale constant at all other locations), resulting in a decrease in demand at both hospitals and a decrease in profits at the combined hospital entity of A and C. Suppose, however, that B is a sufficiently adequate substitute for care at these hospitals so that the increase in profit as a result of the increase in demand for hospital B's services is greater than the decrease in profits at the combined hospital entity of $\mathrm{A}$ and $\mathrm{C}$. Hospitals $\mathrm{A}$ and $\mathrm{C}$ would be a market under the SSNIP criterion, as the collective profits in the systems of which these hospitals are members has increased. Likewise, if hospital D is a close substitute for the care rendered at A and C while hospital B is not, hospital B would see little or no increase in demand or profits and thus hospitals $\mathrm{A}$ and $\mathrm{C}$ would not be considered a market according to the SSNIP criterion.

In the event that a price increase at a given location results in a reduction of sales that would be large enough such that a hypothetical monopolist would not find it profitable to impose an increase in price, the merger guidelines suggest adding the location from which production is the next-best substitute for production at the merging firm's location. Because spatial differentiation is an important attribute of hospital care, when a SSNIP is not profitable, we include additional hospitals in order of their geographic proximity to the location of the merging hospital(s) in question. Our algorithm for implementing

\footnotetext{
${ }^{29}$ The 2010 merger guidelines require that a hypothetical profit-maximizing firm that was the only present or future producer of the relevant product(s) located in the region would impose at least a SSNIP from at least one location, including at least one location of one of the merging firms. They also explicitly state that a single firm may operate in a number of different geographic markets.
} 
SSNIP markets using the structural Bertrand model (SSNIP Market Definition) is as follows:

1. Begin with a hospital for which one would like to define a geographic market.

2. Find the hospital geographically closest to the hospital chosen in step 1 .

3. Raise the price of only these hospitals by a given percentage (we use $5 \%$ ) and allow demand to change as a result of the price increase.

4. If the total difference in profits for the hospital system (given diversion to other hospitals in the same system) is positive, this constitutes a market by the SSNIP test. If it does not, we add the next hospital that is geographically closest to the hospital in step 1.

We repeat this process until the increase in price for the chosen hospitals results in a positive difference in profits. ${ }^{30}$

\section{Comparison Methodology for Implementing the SSNIP Test}

In our implementation of market definition, we employ the two versions of the shipments-based techniques, Elzinga-Hogarty and Critical Loss, detailed in Section II. Specifically, we seek to compare the geographic markets defined by the SSNIP criterion using the structural model with the markets implied by the two most commonly employed quantitative geographic market definition techniques for hospital merger cases.

\footnotetext{
${ }^{30}$ Note that this algorithm allows for hospitals which are close substitutes and also members of the same system to capture each others' demand as the result of a price increase at one of the hospitals. Additionally, because the current merger guidelines require only that a SSNIP be imposed at only one location, our algorithm produces markets that are likely larger than would be implied by the current (2010) revision of the merger guidelines.
} 
In what follows we describe our implementation of market definition using these methods.

\section{Elzinga-Hogarty Simulation}

As previously described, the Elzinga-Hogarty method of geographic market definition uses shipments information consisting of origin and destination data for delineating a market. It specifies the use of the "little in from outside" measure (LIFO) to determine the geographic extent of demand while the "little out from inside" measure (LOFI) determines the geographic extent of supply. The simultaneous satisfaction of a given threshold for each of these measures is evidence of a geographic market. The thresholds recommended in the original article are .75 for a "weak market" and .9 for a "strong market." With regard to hospital care, Elzinga-Hogarty can be thought of as a joint ratio of import and export thresholds by which to judge the self-sufficiency of a particular market. We define the "import" of health care as an individual leaving an area in order to be treated, and the "export" of health care as an individual from another area (other than the one being analyzed) being treated in the relevant area. Elzinga-Hogarty posits that if an area imports little of its health care, it can be deemed a market from the demand perspective, as few individuals see the need to leave the area to be treated. Thus as the import ratio, defined as

$$
\text { import ratio }=\frac{\text { patient outflows from area of interest into any other area }}{\text { total discharges from area of interest }}
$$


gets increasingly small, 1-(import ratio) gets increasingly large. LIFO is thus defined as 1-(import ratio).

Similarly, Elzinga-Hogarty posits that if an area exports little of its health care, it can be deemed a market from the supply perspective. Thus as the export ratio of healthcare defined as

$$
\text { export ratio }=\frac{\text { patient inflows from other areas into this area }}{\text { total discharges from hospitals in this area }}
$$

gets increasingly small, this is equivalent of 1-(export ratio) getting increasingly large. LOFI is thus defined as 1-(export ratio).

There are numerous ways in which Elzinga-Hogarty markets can be calculated. Specifically, the means by which one expands a market that does not meet the prescribed LIFO and LOFI criteria can affect the size of the market determined for a given hospital. Frech et al. (2004) propose six methods for expanding an Elzinga-Hogarty market based on the geographic area from which a given hospital draws its patients. For our purposes, we employ the method of expansion termed "contiguous search" to expand the market. This version of Elzinga-Hogarty market definition proceeds in 3 steps: The first step in expanding the market is to set a threshold at which the simultaneous satisfaction of this threshold for both LIFO and LOFI constitutes a market. The contiguous search method then proceeds by first choosing a zip code for which one would like to calculate an Elzinga-Hogarty market. LIFO and LOFI are calculated for this zip code. If either LIFO or LOFI is less than the prescribed threshold, one chooses the zip code that contributes most to the minimum of LIFO and LOFI, from the universe of zip codes contiguous to 
the zip code of interest. ${ }^{31}$ For each additional zip code, $\mathrm{zj}$, that is contiguous to the combination of zip codes already included in the service area from previous iterations, $\mathrm{Z}-\mathrm{j}$, zip code $\mathrm{z}_{\mathrm{i}}$ is added, one at a time if it satisfies (for each iteration):

$$
z_{i}=\min \left\{\max \left[\operatorname{LIFO}\left(z_{-j}, z_{j}\right)\right], \max \left[\operatorname{LOFI}\left(z_{-j}, z_{j}\right)\right]\right\} \forall z_{j}
$$

Zip codes continue to be added until both LIFO and LOFI equal the prescribed threshold. For our analysis, we use the "weak market" criterion of 0.75 as our threshold. As Frech et al. (2004) detail in their work, this method is one of the two approaches that produce markets which are relatively compact and contiguous, and produce the most realistic geographic markets. In addition, our choice of the weak market threshold of 0.75 rather than the strong market threshold of 0.9 is because in practice, it is virtually impossible to obtain an Elzinga-Hogarty market for hospital care at a threshold of 0.9 for some markets in our data, short of including most of the state.

\section{Critical Loss Simulation}

In Critical Loss analysis, for a given price increase, the percentage reduction in demand, X, that would render a price increase unprofitable is given by Harris and Simons (1989) as

$$
\mathrm{X}=\left[\frac{\mathrm{Y}}{\mathrm{Y}+\mathrm{CM}}\right] * 100
$$

\footnotetext{
${ }^{31}$ Because of data limitations, we use a fixed radius between zip code centroids to create the universe of zip codes by which to expand the market, rather than shared zip code borders.
} 
where $\mathrm{Y}$ is the proportion increase in price (5\% in the case of the SSNIP test) and CM is the contribution margin defined as $\frac{P-A V C}{P} .{ }^{32}$ This value of $X$ is called the "Critical Loss." We employ a method based on previous cases for both the estimated contribution margin as well as the estimated actual loss. Though calculation of contribution margins is theoretically a straightforward exercise, in practice the calculation of these margins for hospitals in merger cases is subject to the discretion of the analyst as to the definition of fixed cost and variable cost. Consequently, our implementation of Critical Loss utilizes approximations of these margins based on past merger cases rather than attempting to extrapolate the classification of costs according to merging parties. The contribution margin assumed in these cases has ranged from $41.4 \%$ in State of California v. Sutter Health System to $65.9 \%$ in FTC v. Tenet. ${ }^{33}$

For our simulation of the estimated loss, we employ a method of determining the "contestable zip codes" for a market of hospitals, meaning the collection of zip codes in which at least a fixed percentage of the patients travel to hospitals other than those posited as a potential market. It is then hypothesized that for these zip codes, if a given increase in price were to be implemented, the demonstrated willingness of individuals in these zip codes to travel outside of the proposed market for care at the present terms of sale is evidence that a sufficient number of substitutes exist. Thus it is put forward that a SSNIP would induce a significant number of these patients to switch to hospitals not implementing such an increase in price. Given that our goal is to approximate Critical Loss markets as determined by previous cases, we utilize a method similar, although not identical, to the contestable zip code method. Whereas the contestable zip code method

\footnotetext{
${ }^{32}$ See Harris and Simons (1989) p. 212-215 for the derivation of these formulas.

${ }^{33}$ Langenfeld and Li (2001) p. 325-329.
} 
determines the contestable zip codes and then states the number from these zip codes that would have to leave in order to make a price increase unprofitable, we instead impose a fixed percentage that would leave contestable zip codes for a given price increase. This step is necessary in order to implement an algorithm to find Critical Loss markets rather than define an arbitrary market and then hypothesize about the behavior of the patients in this area necessary to make this area a market of a given size. Though this actual loss number is not clearly defined and could vary greatly by case, we base our actual loss numbers on the determination in the Sutter case that suggested that the number of patients traveling into the proposed market that would have to switch is between one-third and two-thirds.

Given that the court ruled in favor of the defendant, we interpret this figure to be indicative of the court's conclusion of the likely substitution patterns of hospital patients. ${ }^{34}$ In our calculation of Critical Loss, we apply a contribution margin of 55\% which would determine that the Critical Loss is approximately $8.3 \%$ for a $5 \%$ increase in price. We define zip codes as contestable if $25 \%$ or more patients travel to hospitals other than those being defined in a hypothetical merger. Finally, we assume that of the patients that currently receive care at one of the merging hospitals, $30 \%$ of these patients from zip codes deemed contestable (i.e. have at least $25 \%$ outflows under the pre-merger terms of sale) would substitute to another hospital as a result of a $5 \%$ increase in price. ${ }^{35}$

\footnotetext{
${ }^{34} \mathrm{We}$ do acknowledge, however that the number of patients that were determined to travel into the market accounted for only $15 \%$ of the total discharges in question. The set of contestable zip codes often does constitute a larger subset of discharges than was determined "out of the market" in the Sutter case.

${ }^{35}$ Our algorithm works as follows:

1) Start with a hospital and the hospital closest to this hospital.

2) Find the universe of Diagnosis Related Groups (DRG) served by the hospitals chosen.

3) Find the contestable zip codes given this universe of DRGs.

4) Calculate the actual loss by assuming that $30 \%$ of the patients currently attending the hospitals of interest in the contestable zip codes acquire their care elsewhere.
} 


\section{Data}

We use 1995 data from California's Office of Statewide Health Planning and Development (OSHPD) which maintains a variety of datasets on various aspects of health care in the state. ${ }^{36}$ Below we briefly describe each of the particular datasets we draw upon and the criteria for selecting subsets of the data.

\section{Discharge data}

Among the items collected by OSHPD for each discharge are patient demographics, diagnosis, treatment, an identifier for the hospital at which the patient sought care, the patient's zip code of residence, and charges.

\section{Annual and Quarterly Financial data}

Annual financial disclosures are submitted each fiscal year and every time a hospital changes ownership. From these data, we use information on location of the hospital, ownership of the hospital, type of care provided by the hospital, whether the hospital is a teaching hospital or not, and wages. Quarterly financial disclosures are submitted by calendar quarters, so that they are synchronized both with the discharge data and with one another.

\section{Selections}

5) Compare the loss calculated in (4) to the critical loss figure of $8.3 \%$ of original demand. If actual loss is greater than critical loss, we add the next closest hospital and repeat steps 1-4. If not, the set of hospitals is determined to be a market.

${ }^{36} \mathrm{http}: / /$ www.oshpd.state.ca.us/ 
For 1995, there are a total of 3.6 million patient discharges. For our analysis we use only those discharges whose payment comes from private sources. These are discharges in the HMO, PPO, other private, self-pay, and Blue Cross/Blue Shield categories. This amounts to 1.47 million discharges. Our motivation in making these choices is that for patients in these categories, some entity is making explicit choices among hospitals, based, at least in part, on price. In the case of the various insurance categories, insurers have discretion both over which hospitals to include in their networks of approved providers and via any channeling of patients to less expensive hospitals. We also eliminate patients with a DRG frequency of less than 1,000 , patients with missing values for any of the variables used in any of our analyses, patients with charges less than $\$ 500$ or greater than $\$ 500,000$ and consumers with lengths of stay of zero or greater than 30. After all the exclusions, there are 913,547 remaining observations.

Of the 593 total hospitals in the financial data, we exclude hospitals such as psychiatric hospitals, children's hospitals, rehabilitation hospitals, and other specialty institutions, as well as hospitals associated with staff model HMOs. In addition we exclude hospitals with either missing or useless quarterly financial data (some hospitals had larger deductions from revenue than they had gross revenue, for example). We also exclude hospitals with fewer than 100 discharges for the year. Finally, we drop hospitals whose closest competitor (in terms of distance) is in another state. This is because our data precludes us from observing hospitals in neighboring states which could presumably be reasonable substitutes for those hospitals located on a state border. This leaves us with an analysis sample of 913,547 discharges and 368 hospitals. 


\section{Results}

\section{Statewide Analysis}

In order to compare markets delineated by using the three different methodologies described above, we define markets using Critical Loss, Elzinga-Hogarty and the SSNIP market definition using the structural model for all hospitals in our data.

Table 4 reveals substantial differences in the markets defined by the methodologies in both the number of hospitals in each market, as well as the degree of concentration as defined by the HHI measures. SSNIP market definition using the structural model determines that the median hospital operates in a market of 3 hospitals with an $\mathrm{HHI}$ of $3,814 \cdot{ }^{37}$ This is well above the threshold determined by the merger guidelines as being highly concentrated. In contrast, our version of Critical Loss concludes that the median hospital operates in a market with 16 hospitals and an HHI of 1,194. Elzinga-Hogarty defines markets similar to Critical Loss, with the median hospital operating in a market with 12 other hospitals and an HHI of 1,499. Thus under the merger guidelines, both the Critical Loss and Elzinga-Hogarty methods would find that the median hospital exists in a market that is unconcentrated.

Many health economics studies use political boundaries to define markets, such as Metropolitan Statistical Areas (MSA), or Health Service Areas (HSA), which are defined based on commuting patterns and patient flows respectively (U.S. Census Bureau, 2007, page 895; Makuc, 1991). Therefore we also examine the implications of using these boundaries to define geographic markets. This produces the lowest concentration

\footnotetext{
${ }^{37}$ We use available beds in our calculation of HHI by market. The correlation between beds, total discharges and total patient days and other standard measures of hospital output is above .9 for all measures.
} 
measures of all market definition approaches. Using MSAs to define geographic markets implies that the median hospital operates in a market with 18 hospitals and an HHI of 1,191, while defining geographic markets using HSAs infers that the median hospital operates in a market with 15 other hospitals and an HHI of 1,191 .

A more detailed breakdown of the hospitals by geographic area reveals a substantial amount about the competitive environment for hospitals based upon their location. Dividing the hospitals in the sample into hospital "density quartiles" based on the number of hospitals within a 25 -mile radius exposes the wide variation in the methodologies' market definition for urban and rural areas. Quartile 1 includes hospitals with $0-5$ other hospitals within a 25 -mile radius, quartile 2 includes hospitals with 6-18 other hospitals within a 25-mile radius, quartile 3 includes hospitals with 19-70 other hospitals within a 25-mile radius, while quartile 4 includes hospitals with 71-110 other hospitals within a 25 -mile radius. Figure 1 maps these hospital density quartiles while Table 5 shows the characteristics of hospitals within these quartiles

As can be seen in Figure 1, the wide variability in the number of other hospitals within a 25-mile radius is due to the difference in hospital density in urban and rural areas. In particular, quartile 4 consists entirely of hospitals in Los Angeles County and Orange County, while quartile 3 consists of hospitals from the Los Angeles (44.3\%), San Francisco-San Jose (37.5\%) and San Diego (18.2\%) metro areas. Quartile 1 consists of mostly Northern California hospitals, hospitals in coastal towns and on the far outskirts of metro areas, while quartile 2 comprises a mix of hospitals on the periphery of the 5 major 
metro areas in California, as well as the hospitals located in the central part of the state between San Francisco and Los Angeles. ${ }^{38}$

As would be expected, the size of the geographic markets using all three of the methodologies indicates that markets are more concentrated in areas where there are fewer nearby hospitals and less concentrated in areas where there are more hospitals close by. The magnitude of the concentration difference, however, varies substantially depending on the density quartile. In particular, in quartile 1 , all methodologies indicate that the mean level of market concentration is somewhat high, although the structural model produces markets where the mean level of market concentration is higher than that implied by both Elzinga-Hogarty and Critical Loss. However, in this quartile, ElzingaHogarty and Critical Loss agree with SSNIP market definition on the size of the market in 22 and 10 of the 93 cases respectively, and produce smaller markets in some cases. This stands in contrast to quartile 3 and 4 in which neither shipments-based methodology produces markets of comparable size to markets defined using the structural model.

As is evident from Table 5, all three of the methodologies produce markets that include more hospitals in areas with greater hospital density. However, though the change in the level of concentration by market is directionally equivalent, the magnitudes of the concentration levels differ substantially. This suggests that although the shipments-based methods are consistent in their determination that antitrust markets encompass a larger number of hospitals in areas with greater hospital density (i.e. urban areas), the difference in market sizes determined by these methods are substantially larger than those implied by the structural model, and these differences are greater as the number of surrounding

\footnotetext{
${ }^{38}$ The 5 largest Metro areas in California are Fresno, Los Angeles, Sacramento, San Diego and San Francisco.
} 
hospitals increases. In Los Angeles, for example, in density quartile 4, Elzinga-Hogarty must include an average of 50 hospitals (and over 100 zip codes) in order to produce a market, whereas Critical Loss must include an average of 65 hospitals in order for the loss from contestable zip codes to be sufficiently small so as to produce a market. In contrast SSNIP market definition finds that the average hospital in this quartile operates in a market with just 5 other hospitals. In quartile 1 on the other hand, Elzinga-Hogarty specifies a market with an average of 7.19 hospitals and Critical Loss determines that an average market in this quartile includes 5.8 hospitals. Market definition using the structural model determines that in this quartile, the average hospital market consists of just 2.78 hospitals

The bottom panel of Table 5 also reveals a great deal about the market concentration according to the prescribed thresholds set by the merger guidelines. ${ }^{39}$ Across quartiles, both Critical Loss and Elzinga-Hogarty indicate that markets become less concentrated as we move from quartile 1 to quartile 4 . The percentage of hospitals operating in markets with HHIs of less than 1,500 for Critical Loss increases from $8.6 \%$ in quartile 1 to $100 \%$ in quartile 4. Likewise, for Elzinga-Hogarty, the percentage of hospitals in markets with HHIs of less than 1,500 increases from $16.1 \%$ in quartile 1 to $100 \%$ in quartile 4 . SSNIP market definition using the Bertrand model finds only five markets with HHIs of less than 1,500 in any concentration quartile.

The number of markets considered highly concentrated (HHI greater than 2,500) also show significant changes across concentration quartiles. The percentage of hospitals operating in markets with HHIs of greater than 2,500 according to Critical Loss decreases

\footnotetext{
${ }^{39}$ While the guidelines specify thresholds for post-merger market shares, the HHIs discussed below are premerger market shares. Nevertheless, we use them as reference points in our analysis.
} 
from $68.8 \%$ in quartile 1 to $0 \%$ in quartile 4 . Similarly, the Elzinga-Hogarty method determines that $51.6 \%$ of hospitals operate in markets with an $\mathrm{HHI}$ of greater than 2,500 in quartile 1, while in quartile 4 no hospitals operate in a market with an $\mathrm{HHI}$ of such magnitude. SSNIP market definition conversely shows all but three hospitals operating in a market with an $\mathrm{HHI}$ of greater than 2,500 in quartiles 1 and 2, and just $12.5 \%$ and $48.4 \%$ of hospitals in quartiles 3 and 4 operating below the 2,500 threshold respectively.

\section{Elasticities}

The structural model allows for the calculation of the elasticity of demand for each hospital. As shown in Table 3, the average own-price elasticity of demand for a hospital in the sample is calculated as -4.57 . Table 6 indicates that this elasticity varies by density quartile, as the average elasticity of demand for hospitals increases (in absolute value) from 3.55 in quartile 1 to 5.48 in quartile 4 . This suggests that hospitals in areas with more nearby competitors do in fact face stiffer competition than those with a lower number of nearby hospitals. While this increase in own-price elasticity using the structural model is notable in and of itself, as Table 5 indicates, both the Elzinga-Hogarty and Critical Loss methodologies produce significantly larger markets in all density quartiles, thus implying a much flatter demand curve for each hospital and consequently a larger elasticity than estimated by the structural model.

Because the estimated consumer utility in equation (1) depends on price, all firmlevel elasticities are a function of the price parameter contained in the specified utility function, $\alpha_{p}$. Thus, the larger elasticities produced by the two comparison methodologies are equivalent to consumers exhibiting more price sensitive behavior, or equivalently, 
that the value of $\alpha_{p}$ in the utility function is of larger (absolute) magnitude than is estimated in the structural model. Thus, if we solve for this value of $\alpha_{p}$ that produces markets of equivalent size to our comparison methods, we can determine the elasticities that would be required in order to produce markets of equivalent size to those implied by Elzinga-Hogarty and Critical Loss for a $5 \%$ price increase. ${ }^{40}$

In the top portion of Table 7, we include a summary by hospital density quartile of the average own-price elasticity in a hospital market determined by the ElzingaHogarty and Critical Loss methodologies according to the structural model. For example, for the 93 hospital markets calculated using Elzinga-Hogarty in density quartile 1, the average own-price elasticity as calculated using the estimated price parameter in the structural model is -3.60 . In the lower panel, we present the elasticities that would be implied by the structural model in order to make the markets determined by ElzingaHogarty and Critical Loss consistent with the price elasticity assumptions of the structural model. For example, for the same 93 hospital markets calculated using Elzinga-Hogarty in density quartile 1 , the value of this price parameter that would make consumers sufficiently price sensitive so as to produce an equivalent market to that determined by Elzinga-Hogarty would imply that the average own-price elasticity in these 93 markets is -10.10. Thus the differences in these implied elasticities demonstrate that both ElzingaHogarty and Critical Loss implicitly substantially overstate the price sensitivity of consumers with regards to hospital care. Looking across all quartiles, Table 7 shows that Critical Loss overstates the magnitude of elasticities of a hospital in the median hospital market by a factor ranging from 2.4 in quartile 1 to 3.4 in quartile 4, while Elzinga-

\footnotetext{
${ }^{40} \mathrm{We}$ solve for this value of $\alpha_{p}$ which equates the two markets using a binary search algorithm for each market.
} 
Hogarty overstates these elasticities by a factor ranging from 2.3 in quartile 3 to 2.6 in quartile 1.

These elasticity differences also suggest that the implied markups for hospital care using these informal methods are smaller than the markups that are assumed when analyzing actual hospital merger cases. The commonly used Lerner Index, $\frac{p-m c}{p}=\frac{1}{\epsilon}$, relates elasticity to margins, implying that the determination of high margins indicates a low elasticity of demand. In the calculation of Critical Loss, the contribution margin defined in the previous section is equivalent to the left-hand side of a Lerner Index (assuming constant returns to scale). Thus from our elasticity estimates in Table 7, we can infer that the percentage markup over marginal cost implied by the Critical Loss market size is lower than the $55 \%$ that was actually used in our definition of the Critical Loss markets. As Table 7 indicates, even in the lowest hospital concentration quartile, the markup for a hospital in the median hospital market using the Critical Loss methodology is $12 \%$, while in quartile 4 , the implied markup in the market for the median hospitals is $5.4 \%$. Although Elzinga-Hogarty in its implementation does not explicitly postulate as to the implied markup, it suffers from similar shortcomings in that it suggests markups ranging from $7.4 \%-9.9 \%$ for a hospital in the median hospital market, well below those implied by the elasticity estimates in the structural model. Both of these findings suggest that the market definition techniques used in previously decided merger cases are inappropriate for hospital market definition; that is, using shipments based techniques will by and large produce overestimates of the price elasticity of demand faced by hospitals, thus resulting in substantially larger markets than intended in the merger guidelines. 


\section{An Analysis of San Diego}

To further demonstrate market definition under the SSNIP criteria, we examine markets defined in a localized area of the state. Specifically, we perform market definition in the San Diego area. Our selection of San Diego is strategic in that it is an area with few geographic barriers and it contains a reasonable number of hospitals so as to allow for methodological illustration while still being computationally feasible. It also allows us to compare the markets defined by our structural model with those delineated by a related, and influential, model of hospital competition developed by Capps, Dranove, and Satterthwaite (2003) and applied to proposed consolidations in New York State by Dranove and Sfekas (2009).

Capps et al. (2003) present a model (based on Town and Vistnes, 2001) in which insurers bargain with hospitals and the market power of a hospital is based on the willingness to pay (WTP) of a group of consumers for the use of that particular hospital. This model is estimated on data from San Diego, so comparisons using this method are restricted to that area.

A summary of the San Diego area hospitals is presented in Table 8, while a map of the hospitals in the area is presented in Figure 2. San Diego contains hospitals that fall into hospital density quartiles 2 and 3. The dominant systems in the area in our 1995 data are the Scripps and Sharp systems, with each controlling 6 and 5 of the 23 hospitals respectively. While 19 of the 23 hospitals were members of a multi-hospital system, 4 of these hospitals, Alvarado, Harbor View, Mission Bay and Paradise Valley were owned by corporations that controlled no other hospitals in the San Diego area. The other two 
multi-hospital systems, University of California (UC) and Palomar Pomerado, each controlled only two hospitals.

Table 9 presents the results of SSNIP market definition for the San Diego area for each of our three market definition methodologies. As evidenced in Table 8, San Diego County had a moderate degree of concentration in 1995, with a system-based HHI of $1,949 .{ }^{41}$ With the exception of Fallbrook Hospital, all methods produce a market which is a subset of the hospitals in this county. ${ }^{42}$ Critical Loss in column one defines markets as consisting of 13-38 hospitals, each of which comprise substantial subsections of the San Diego area, and in the case of Fallbrook Hospital, portions of the Los Angeles Area. Similarly, Elzinga-Hogarty market definition in column two determines that markets are anywhere from 14-19 hospitals in size. The structural model in column three, however, shows that SSNIP markets consist instead of small sets of no more than 4 hospitals, with a median market size of two hospitals. This difference in methodology evidently affects the degree of concentration implied in the San Diego area. Both of the comparison methods produce markets with the majority of HHIs falling in the 2,000-3,000 range, while no SSNIP market produced by the structural Bertrand model has a HHI lower than 3,000 and 18 of the 23 hospitals operate in a market with an HHI of more than 5,000.

Figure 3 illustrates the differences in markets produced by the three methodologies, using as an example the definition of a market for Scripps Memorial Hospital - Chula Vista (Scripps Chula Vista), a 159-bed hospital located in the southern portion of the San Diego metropolitan area. Using the SSNIP market definition

\footnotetext{
${ }^{41}$ This HHI measure takes into account system membership and is highly correlated (correlation of over .9) with total discharges and total patient days.

${ }^{42}$ In order to create a critical loss market for Fallbrook Hospital, the northernmost hospital in the sample, the algorithm expands into the Southern section of the Los Angeles Metropolitan Area.
} 
algorithm, Scripps Chula Vista and Community Hospital of Chula Vista, a 306-bed hospital located in the same area represent a geographic market, with a HHI of 5,500. Using Elzinga-Hogarty, a geographic market would include these two hospitals, as well as 16 other facilities in the San Diego area, producing a market with an HHI of 2,228. The market produced using Critical Loss shows a similar pattern, as a critical loss market would include a total of 17 hospitals in the San Diego metropolitan area, implying that Scripps Chula Vista operates in a market with an HHI of 2,692.

\section{Comparison with the Willingness to Pay Model}

The Willingness to Pay (WTP) model represents a promising method of analyzing mergers (Capps et al., 2003; Town and Vistnes, 2001). Because both the structural Bertrand model and WTP models are both rooted in a multinomial-logit demand specification which includes both hospital and consumer characteristics and patienthospital distance, we present results from a comparison of merger simulations using the structural Bertrand model to compare price increases implied by the WTP model (see Appendix A for a brief overview of the WTP model). ${ }^{43}$ The main differences between the models involves the determination of firm pricing behavior; firm conduct and price determination are not modeled explicitly in the WTP model, rather the relationship between WTP and hospital profits is identified using a regression of hospital profits on WTP for each hospital. Mergers in the model are simulated by calculating the difference in WTP for a combined entity of hospitals and the sum of the WTP for each separate hospital in this combined entity. Using the relationship between a "unit" of WTP and hospital profits (calculated from the regression of hospital profits on WTP), and assuming

\footnotetext{
${ }^{43}$ Details of our estimation of the WTP model are included in appendix A.
} 
no change in the cost of treatment, this difference in WTP is used to show the increase in average revenue per patient brought about by the merger, leaving quantity unchanged.

The WTP model does not allow for market definition in a localized area where a large hospital firm (system) controls multiple plants (hospitals). This is due to the difficulty in allocating the willingness to pay measure across hospitals of the same system affiliation. Consequently, we adapt the structural Bertrand model to simulate mergers between individual hospitals, as well as individual hospital systems, thereby enabling directly comparable merger effects for each model. For our estimates of the WTP, we employ the same variables in our utility function as were used in Capps et al. (2003) with minor exceptions. ${ }^{44}$ Furthermore, use of the WTP necessitates a different sample of consumers than was used in that of Capps et al. (2003) as the original estimated WTP utility function includes Medicare patients, indemnity patients and HMO/PPO. In order to ensure the most direct comparison of the two methods, we include only indemnity and HMO/PPO consumers. ${ }^{45}$

Table 10 includes the results of the mergers of 27 mergers of independent hospitals located in the San Diego area. ${ }^{46,47}$ As Table 10 demonstrates, the two models show merger effects on price that are virtually zero for the independent San Diego hospitals. For the mergers in Table 10, for only one merger, that of Tri-City Hospital and

\footnotetext{
${ }^{44}$ Instead of the "equipment intensity" variable, we use a "tech index" variable which is the sum over dummy variables for the presence of 28 technologies reported in the annual hospital financial data (such as presence of an MRI, open heart surgical suite, etc.). Also, instead of travel time, we use distance.

${ }^{45}$ This corresponds to specification (4) in Capps et al. (2003)

${ }^{46}$ We display the results of independent hospitals primarily because Capps et. al. do not prescribe a method of calculating WTP for markets in which a hospital system controls multiple hospitals. Thus these are the "cleanest" comparisons of the two methodologies.

${ }^{47}$ We classify a hospital as independent for purposes of this analysis if the hospital had was not a member of a hospital system or if the hospital was owned by a corporation that controlled only one hospital in the San Diego area.
} 
Fallbrook Hospital, do the methods differ on whether a merger would produce a SSNIP. They are otherwise in agreement.

Calculation of WTP does not allow for isolation of unilateral merger effects; rather it determines the aggregate price increase implied by a merger in a chosen market. Thus we adjust the model to account for system membership; specifically we calculate the WTP measure for each hospital separately and given these estimates, we can then infer the WTP for an entire hospital system. The effect of a system merger can then be identified using the difference in the aggregate WTP for both systems versus the WTP for each system separately. Table 11 presents the results of the merger of 5 hospital systems in the San Diego area.

In three of the five system mergers presented in Table 11, both models agree on which mergers would result in a $5 \%$ increase in price. ${ }^{48}$ For the two mergers presented in Table 11 in which the two methods do not agree, both of these mergers involve the University of California, San Diego, a hospital which generates the largest WTP measure of all hospitals in our data. As Capps et al. (2003) indicate in their paper, this could be due to UCSD's status as the only university hospital in the market. This fact, coupled with UCSD's service area overlap with Scripp's Mercy Hospital (0.4 miles from UCSD) and Sharp Memorial Hospital (3.2 miles from UCSD) in downtown San Diego most likely accounts for the substantial increase in WTP (and thus price) induced by a merger of UCSD with both Sharp and Scripps. In the structural Bertrand model, however, UCSD Medical Center charges the highest price for a unit of hospital care in the San Diego

\footnotetext{
${ }^{48}$ The correlation between the merger simulations and WTP model is 0.82 . Furthermore, thought the merger simulations allow for identification of individual merger effects, in order to facilitate a direct comparison of the two methodologies, we weight the price increases produced by the structural Bertrand model's merger simulations by the demand at each hospital (pre-merger).
} 
$(\$ 5,827)$ area while also exhibiting the highest own-price elasticity $(-5.99)$ of San Diego area hospitals (with the exception of Villa View Hospital). This pattern is suggestive of the UCSD Medical Center exerting market power in its pricing of hospital services. Consequently, while a merger of UCSD with hospital systems in the area does produce an increase in price using the structural Bertrand model, this increase is most likely not as large as would be the case if UCSD were not already exerting market power. To the degree that consumers and health insurers substitute to other health care providers as a result of the prevailing high price at UCSD Medical Center, the observed elasticity may account for the lower price increase implied by the merger of these systems in the structural Bertrand model.

Overall, the results of the comparisons between these two methods reveal a notable degree of similarity for hospital merger effects in the San Diego area. Though the models differ in their assumptions about firm conduct, given that both models identify demand-side merger effects via the intersection of patient market shares, such a result is not surprising.

\section{Conclusion}

Market definition is essential for merger analysis, and has played a pivotal role for antitrust decisions in the hospital industry in the past two decades. The vast majority of hospital merger cases have utilized ad hoc methods of geographic market definition that rely heavily upon patient shipment data, with no explicit economic model used to justify such methods. Our use of a fully specified structural model of hospital competition compares commonly employed geographic market definition approaches used in actual 
hospital merger cases to geographic markets rooted in the principles set forth by the merger guidelines. This method explicitly models consumer and producer behavior, and also accounts for firms operating at multiple locations, as required by the 2010 merger guidelines.

We find that the use of approaches frequently utilized in previous cases largely overstate the size of geographic markets for hospitals, particularly in areas with greater hospital density. In addition, these informal approaches imply elasticities ranging from 2.4-3.4 times as large as those calculated from a structural model of hospital competition. Furthermore, our analysis of the San Diego area is consistent with those implied by the model of Capps et al. (2003).

The results have important implications for merger analysis in both the hospital industry and other industries involving differentiated products. They illustrate the importance of economic modeling for defining markets, and indicate that reliance on imprecise methods of market definition has the potential to mislead the courts as to the appropriate extent of geographic markets. The markets presented here are most consistent with those identified in merger cases by plaintiffs rather than by defendants, in contrast to the court's frequent rejection of markets alleged by the antitrust authorities. Thus the use of such an approach should be emphasized when assessing the extent of market power in this and other differentiated product industries. 


\section{References}

American Bar Association, 2003. Health Care Mergers and Acquisitions Handbook. Chicago: ABA Publishing.

Baker, J., 2007. Market Definition: An Analytical Overview. Antitrust Law Journal, 74, pp.129-173.

Baker, J. and Bresnahan, T., 1985. The Gains From Merger or Collusion in ProductDifferentiated Industries. The Journal of Industrial Economics, 33(4), pp.427-444.

Berry, S., Levinsohn, J. \& Pakes, A., 2004. Differentiated Products From a Combination of Micro and Macro Data: The New Car Market. Journal of Political Economy, 112(1), pp.68-105.

Capps, C., \& Dranove, D., 2004. Hospital Consolidation and Negotiated PPO prices. Health Affairs 23(2), pp.175-181.

Capps, C., Dranove, D., Greenstein, S. \& Satterthwaite, M., 2001. The Silent Majority Fallacy of the Elzinga-Hogarty Criteria: A Critique and New Approach to Analyzing Hospital Mergers. National Bureau of Economic Research Working Paper No. W8216.

Capps, C., Dranove, D., \& Satterthwaite, M., 2002. Antitrust Policy and Hospital Mergers: Recommendations for a New Approach. Antitrust Bulletin 47(4), pp.677-714.

Capps, C., Dranove, D., \& Satterthwaite, M., 2003. Competition and Market Power in Option Demand Markets. RAND Journal of Economics 34(4), pp.737-763.

Crooke, P., Froeb, L., Tschantz, S. \& Werden, G.J., 1999. Effects of Assumed Demand Form on Simulated Postmerger Equilibria. Review of Industrial Organization, 15(3), pp. $205-217$.

Dafny, L. 2009. Estimation \& Identification of Merger Effects: An Application to Hospital Mergers. Journal of Law and Economics, 52(3), pp.523-550.

Danger, K. L. \& Frech, H.E. III, 2001. Critical Thinking about Critical Loss in Antitrust. Antitrust Bulletin, 46(2), pp.339-355.

Dranove, D. \& Sfekas, A., 2009. The Revolution in Health Care Antitrust: New Methods and Provocative Implications. The Milbank Quarterly, 87(3), pp.607-632.

Duan, N., 1983. Smearing Estimate: A Nonparametric Retransformation Method. Journal of the American Statistical Association, 78(383), pp.605-610.

Elzinga, K.G. \& Hogarty, T.F., 1973. The Problem of Geographic Market Definition in Antimerger Suits. Antitrust Bulletin, 18(1), pp.45-81. 
Elzinga, K, and T. Hogarty. 1978. "The Problem of Geographic Market Delineation Revisited: The Case of Coal." Antitrust Bulletin, 23 (1): 1-18.

Epstein, R.J. \& Rubinfeld, D.L., 2004. Effects of Mergers Involving Differentiated Products. Technical Report for Directorate-General Competition, European Commission [Online]. Available at:

http://ec.europa.eu/competition/mergers/studies_reports/effects_mergers_involving_diffe rentiated products.pdf [Accessed 13 June 2010].

Federal Trade Commission and U.S. Department of Justice, 1992. Horizontal Merger Guidelines, (issued 1992, revised 1997), http://www.ftc.gov/bc/docs/horizmer.shtm (accessed December 7, 2010).

Federal Trade Commission and U.S. Department of Justice, 2010. Horizontal Merger Guidelines, http://www.ftc.gov/os/2010/08/100819hmg.pdf (accessed December 5, 2010).

Frech, H.E. III, Langenfeld, J., \& McCluer, R. F., 2004. Elzinga-Hogarty Tests and Alternative Approaches for Market Share Calculations in Hospital Markets. Antitrust Law Journal 71(3), pp.921-947.

Froeb, L. \& Werden, G.J., 1992. The Reverse Cellophane Fallacy in Market Delineation. Review of Industrial Organization, 7(2), pp.241-247.

Froeb, L.M. \& Werden, G.J., 2000. An Introduction to the Symposium on the Use of Simulation in Applied Industrial Organization. International Journal of the Economics of Business, 7(2), pp.133-137.

Gaynor, M. \& Vogt, W.B., 2000. Antitrust and Competition in Health Care Markets. In A.J. Culyer and J.P. Newhouse, eds. Handbook of Health Economics, Vol. 1B. New York: North-Holland. Ch.27.

Gaynor, M. \& Vogt, W.B., 2002. Competition Among Hospitals. National Bureau of Economic Research Working Paper No. W9471.

Gaynor, M. \& Vogt, W.B., 2003. Competition Among Hospitals. RAND Journal of Economics, 34(4) pp.764-785.

Geroski, P. and Griffith, R. 2004. Identifying anti-trust markets. International Handbook of Competition, M. Neumann and J. Weigand (eds.), Cheltenham, UK: Edward Elgar.

Hamilton, B. \& Ho, V., 2000. Hospital Mergers and Acquisitions: Does Market Consolidation Harm Patients? Journal of Health Economics, 19(5) pp.767-791. 
Harris, R. \& Simons J.J., 1989. Focusing Market Definition: How Much Substitution is Necessary? Research in Law and Economics, 12, pp.207-226.

Hausman, J., Leonard, G. \& Zona, J. D., 1994. Competitive Analysis with Differentiated Products. Annales d'Economie et de Statistique, 34, pp.159-180.

Horowitz, I. 1987. Market Definition in Antitrust Analysis: A Regression-Based Approach. Southern Economic Journal, 48(1), pp.1-16.

Ivaldi, M. and Lörincz, Sz. 2009. "Implementation Relevant Market Tests in Antitrust Policy: Application to Computer Servers", Review of Law and Economics, forthcoming.

Katz, M., \& C. Shapiro, 2003. Critical Loss: Let's Tell the Whole Story. Antitrust, 17(2), pp.49-56.

Keeler, E.B., Melnick, G., \& Zwanziger, J., 1999. The Changing Effects of Competition on Non-Profit and For-Profit Hospital Pricing Behavior. Journal of Health Economics, 18(1), pp.69-86.

Langenfeld J. \& Li, W., 2001. Critical Loss Analysis in Evaluating Mergers. Antitrust Bulletin, 46(2), pp. 299-337.

Leibenluft, R.F. Esq., 1998. Antitrust Enforcement and Hospital Mergers: A Closer Look, [Online]. Available at: http://www.ftc.gov/bc/hmerg1.htm [Accessed 8 March 2010].

Luke R.D., Ozcan Y.A. \& Olden P.C., 1995. Local Markets and Systems: Hospital Consolidations in Metropolitan Areas. Health Services Research, 30(4), pp.555-75.

Makuc, D., B. Haglund, D. Ingram and J. Kleinman 1991. Health Service Areas for the United States, Vital and Health Statistics, Series 2, No. 112 (National Center for Health Statistics).

Majoras, D.P., 2007. “Opinion of the Commission," In the Matter of Evanston Northwestern Healthcare Corporation, Docket No. 9315, http://www.ftc.gov/os/adjpro/d9315/070806opinion.pdf, accessed 7/6/2010.

Miles, J.J., 2005. Health Care and Antitrust Law. St. Paul, MN: West Group.

McCarthy, T.R. \& Thomas, S. J., 2003. Geographic Market Issues in Hospital Mergers. In American Bar Association Health Care Mergers and Acquisitions Handbook. Chicago, ABA Publishing. Ch. 3.

Morrisey, M.A., Sloan, F.A., \& Valvona J., 1988. Defining Geographic Markets for Hospital Care. Law and Contemporary Problems, 51(2), pp.165-194. 
Motta, M. Competition Policy: Theory and Practice. Cambridge, UK: Cambridge University Press.

Peters, C., 2006. Evaluating the Performance of Merger Simulation: Evidence from the U.S. Airline Industry. The Journal of Law and Economics, 49(2), pp. 627-649.

Pitofsky, R., 1990. New Definitions of Relevant Market and the Assault on Antitrust. Columbia Law Review, 90(7), pp.1805-1864.

Scheffman, D. \& Spiller, P., 1987. Geographic Market Definition Under the U.S. Department of Justice Merger Guidelines. Journal of Law and Economics, 30(1), pp.123147.

Scheffman, D., Coate, M., \& Silvia, L., 2002. 20 Years of Merger Guidelines Enforcement at the FTC: An Economic Perspective. Federal Trade Commission, [Online]. Available at: http://www.justice.gov/atr/hmerger/11255.pdf [Accessed 8 March 2010].

Shrieves, R.E., 1978. Geographic Market Areas and Market Structure in the Bituminous Coal Industry. The Antitrust Bulletin, 23, pp. 589-625.

Simpson, J., 2003. Geographic Markets in Hospital Mergers: A Case Study. International Journal of the Economics of Business, 10(3), pp.291-303.

Spiller, P. T. \& Huang, C. J., 1986. On the Extent of the Market: Wholesale Gasoline in the Northeastern United States. Journal of Industrial Economics, 35(2), pp. 131-45.

Stigler, G.J \& Sherwin, R.A., 1985. The Extent of the Market. Journal of Law \& Economics, 28(3), pp.555-85.

Strunk, B.C., Devers, K. \& Hurley R.E., 2001. Health Plan-Provider Showdowns on the Rise" Issue Brief, [Online]. No. 40. Available at:

http://www.hschange.org/CONTENT/326 (Center for Studying Health System Change) [Accessed 8 March 2010].

Town, R. \& Vistnes, G., 2001. Hospital competition in HMO networks. Journal of Health Economics, 20(5), pp.733-753.

Town, R., Wholey, D., Feldman, R. \& Burns, L. R., 2005. The Welfare Consequences of Hospital Mergers. National Bureau of Economic Research Working Paper No. 12244, Cambridge, MA.

Town, R. and Vogt, W., 2006. How has hospital consolidation affected the price and quality of hospital care? Research Synthesis Report No. 9, Robert Wood Johnson Foundation, Princeton, NJ. 
Train, K. (2003). Discrete Choice Methods with Simulation. Cambridge: Cambridge University Press.

United States Census Bureau (2007). The 2007 Statistical Abstract: The National Data Book.

Van Reenen, J. 2004. Is There a Market for Work Group Servers? Evaluating Market Level Demand Elasticities using Micro and Macro Models. Centre for Economic Performance, London School of Economics and Political Science, London, UK

Varkevisser, M., Capps, C. S. \& Schut, F.T., 2008. Defining Hospital Markets for Antitrust Enforcement: New Approaches and their Applicability to the Netherlands. Health Economics, Policy and Law, 3, pp. 7-29.

Viscusi W.K., Vernon J.M. \& Harrington J.E., 2000. Economics of Regulation and Antitrust. Cambridge, MA: MIT Press.

Vita, M.G., \& Sacher, S., 2001. The Competitive Effects of Not-for-Profit Hospital Mergers: A Case Study. Journal of Industrial Economics, 49(1) pp.63-84.

Werden, G.J., 1981. The Use and Misuse of Shipments Data in Defining Geographic Markets. Antitrust Bulletin, 26(4) pp.719-737.

Werden, G. J. Simulating the Effects of Differentiated Products Mergers: A Practitioners' Guide. In Caswell, J.A., and Cotterill, R.W., eds., Strategy and Policy in the Food System: Emerging Issues. Food Marketing Policy Center, Storrs, CT, 1980, pp. 95-110.

Werden, G.J., 1992. The History of Antitrust Market Delineation. Marquette Law Review $76,123-215$.

Werden, G., 1990. The Limited Relevance of Patient Migration Data in Market Delineation for Hospital Merger Cases. Journal of Health Economics, 8(4), pp. 363-76. 


\section{Appendix A: The Capps, Dranove and Sattherwaite Model of Option Demand}

\section{A.1 Consumers}

Consumers are assumed to maximize ex post expected utility. Thus they maximize the expected utility of obtaining treatment for a specific condition at a specific hospital, but before treatment is actually obtained. The utility function is defined as

$$
U_{i j}=U\left(R_{j}, S_{j}, T_{i j}, Y_{i}, Z_{i}\right)-\gamma\left(Y_{i}, Z_{i}\right) p_{j}+\varepsilon_{i j}
$$

where $R_{j}$ is a vector of hospital characteristics that are common across all patient conditions, $S_{j}$ is a vector of variables that contain patient specific service offerings, $T_{i j}$ is the travel time from patient $\mathrm{i}$ to hospital $\mathrm{j}, Y_{i}$ is a vector of the patient's socioeconomic characteristics, and $Z_{i}$ is a vector of clinical attributes specific to patient i. Assuming that $\gamma\left(Y_{i}, Z_{i}\right)$ is constant, individual $\mathrm{i}$ will select hospital $\mathrm{j}$ if for all hospitals $\mathrm{j} \neq \mathrm{k}$,

$$
U\left(R_{j}, S_{j}, T_{i j}, Y_{i}, Z_{i}\right)-U\left(R_{k}, S_{k}, T_{i k}, Y_{i}, Z_{i}\right)>\varepsilon_{i k}-\varepsilon_{i j} .
$$

Assuming $\varepsilon$ is distributed i.i.d. extreme value, the probability $s_{i j}$ that patient $i$ chooses

hospital $\mathrm{j}$ is given as $s_{i j}=\frac{\exp \left(U\left(R_{j}, S_{j}, T_{i j}, Y_{i}, Z_{i}\right)\right)}{\sum_{k \in G} \exp \left(U\left(R_{k}, S_{k}, T_{i k}, Y_{i}, Z_{i}\right)\right)}$ where $\mathrm{G}$ is a network of hospitals from which the patient chooses. The the parameter estimates for our calculation of the utility function are included in Table A.1.

The patient's interim expected utility is thus

$$
V^{I U}=E\left\{\max _{j \in G}\left[U\left(R_{j}, S_{j}, T_{i j}, Y_{i}, Z_{i}\right)\right]\right\}=\ln \left[\sum_{j \in G} \exp \left(U\left(R_{j}, S_{j}, T_{i j}, Y_{i}, Z_{i}\right)\right)\right] .
$$

Given this result, hospital j's contribution to individual i's expected utility is

$$
\Delta V_{j}^{I U}\left(G, Y_{i}, Z_{i}, \lambda_{i}\right)=\ln \left[\frac{1}{1-s_{i j}\left(G, Y_{i}, Z_{i}, \lambda_{i}\right)}\right]
$$


where $\lambda_{i}$ is the location of consumer i. Capps et al. then define the ex-ante willingness to pay for patient i as $\int_{Z} \frac{\Delta V_{j}^{I U}\left(G, Y_{i}, Z_{i}, \lambda_{i}\right)}{\gamma\left(Y_{i}, Z_{i}\right)} f\left(Z_{i} \mid Y_{i}, \lambda_{i}\right) d Z_{i}$. Because this willingness to pay is identified only up to the scale factor $\gamma\left(Y_{i}, Z_{i}\right)$, summing over all consumers the willingness to pay for hospital $\mathrm{j}$ is thus written as

$$
\overline{\Delta W_{j}^{E A}}(G)=N \int_{Y, Z, \lambda} \ln \left[\frac{1}{1-s_{i j}\left(G, Y_{i}, Z_{i}, \lambda_{i}\right)}\right] f\left(Z_{i}, Y_{i}, \lambda_{i}\right) d Y_{i} d Z_{i} d \lambda_{i} .
$$

\section{A.2 Pricing}

After the willingness to pay measure is calculated for hospitals, Capps et al. regress hospital profits on the willingness to pay measure (without a constant) and recover the coefficient from this regression, $\hat{a}$. This generates the predicted impact of WTP on hospital profits. Using the average revenue and average cost per discharge at a hospital, they then calculate a measure of profits per discharge at each hospital.

\section{A.3 Merger Effects using WTP}

The first step in using WTP to simulate merger effects entails calculating the difference in willingness to pay for a merged entity versus the willingness to pay for each entity independently. Defining

$$
\overline{\Delta W_{j+k}^{E A}}(G)=N \int_{Y, Z, \lambda} \ln \left[\frac{1}{1-s_{i j}\left(G, Y_{i}, Z_{i}, \lambda_{i}\right)-s_{i k}\left(G, Y_{i}, Z_{i}, \lambda_{i}\right)}\right] f\left(Z_{i}, Y_{i}, \lambda_{i}\right) d Y_{i} d Z_{i} d \lambda_{i},
$$

the increase in WTP as a result of a merger would thus be

$$
\overline{\Delta W_{j+k}^{E A}}(G)-\overline{\Delta W_{j}^{E A}}(G)-\overline{\Delta W_{k}^{E A}}(G) .
$$

As Capps et al. detail in their paper, if two hospitals are far enough apart, then if hospital $\mathrm{j}$ has a positive market share in market segment $\left(Z_{i}, Y_{i}, \lambda_{i}\right)$, hospital $\mathrm{k}$ will likely have a 
zero market share in that same segment. Thus the expression $\overline{\Delta W_{j+k}^{E A}}(G)-\overline{\Delta W_{j}^{E A}}(G)-\overline{\Delta W_{k}^{E A}}(G)$ will be zero and thus a merger of hospitals $\mathrm{j}$ and $\mathrm{k}$ will likely generate no increase in the market power of the two firms.

The second step in using WTP to simulate merger effects involves inferring the increase in profits resulting from a merger of two firms. Capps et. al. do this by calculating the increase in profits to the entity $(\mathrm{j}+\mathrm{k}), \Delta \hat{\pi}_{j+k}$, as

$$
\Delta \hat{\pi}_{j+k}=\hat{a}\left[\overline{\Delta W_{j+k}^{E A}}(G)-\overline{\Delta W_{j}^{E A}}(G)-\overline{\Delta W_{k}^{E A}}(G)\right]
$$

Profits are then calculated for the merged entity as $\pi_{j}+\pi_{k}+\Delta \hat{\pi}_{j+k}$. Price increases are then inferred as the price changes implied by the changes in profits, assuming quantity does not change. 


\section{Appendix B: Definition of a SSNIP Market}

\section{SSNIP Definition}

Formally, given demand for each hospital as a function of its price, the SSNIP market for a hospital is defined as follows:

A SSNIP market for hospital $\mathrm{j}$, is the set of hospitals, $\mathrm{M}$, (of which hospital $\mathrm{j}$ is a member), such that given a vector of pre-SSNIP prices $\mathrm{p}$ and post-SSNIP prices $\mathrm{p}$ '

1) $\sum_{s} \pi_{s}\left(p^{\prime}\right)-\pi_{s}(p)>0$ for hospital systems with at least one plant in $M$ and

2) $\mathrm{M}$ is the smallest set of hospitals such that (1) holds

where $p_{k}^{\prime}=(1.05) * p_{k}$ if hospital $\mathrm{k}$ is a member of $\mathrm{M}$ and $p_{k}^{\prime}=p_{k}$ otherwise. 
Table A.1 WTP Parameter Estimates

\begin{tabular}{|c|c|c|c|c|c|c|}
\hline \multicolumn{3}{|c|}{$\begin{array}{l}\text { Conditional (fixed-effects) logistic regression } \\
\text { Number of obs }=1381200 \\
\text { LR chi2 }(68)=126728.31 \\
\text { Prob }>\text { chi } 2=0.0000 \\
\text { Log likelihood }=-119532.84\end{array}$} & \multicolumn{4}{|l|}{ Pseudo R2 $=0.3464$} \\
\hline & Coef. & std. error & $\mathbf{Z}$ & $\mathbf{P}>|\mathbf{z}|$ & {$[95 \% \mathrm{Co}$} & Interval] \\
\hline $\mathrm{fp}$ & -0.546 & 0.109 & -5.030 & 0.000 & -0.759 & -0.334 \\
\hline teach & 0.984 & 0.069 & 14.210 & 0.000 & 0.848 & 1.119 \\
\hline transplant & 0.372 & 0.015 & 25.150 & 0.000 & 0.343 & 0.401 \\
\hline nurs_int & -0.187 & 0.011 & -16.620 & 0.000 & -0.209 & -0.165 \\
\hline tech_ind & 0.104 & 0.006 & 18.710 & 0.000 & 0.093 & 0.115 \\
\hline distance & -0.275 & 0.004 & -64.550 & 0.000 & -0.283 & -0.266 \\
\hline distXfp & 0.013 & 0.001 & 13.270 & 0.000 & 0.011 & 0.014 \\
\hline distXteach & 0.010 & 0.001 & 18.460 & 0.000 & 0.009 & 0.011 \\
\hline distXnurs & 0.001 & 0.000 & 3.710 & 0.000 & 0.000 & 0.001 \\
\hline distXtech & 0.001 & 0.000 & 10.330 & 0.000 & 0.001 & 0.001 \\
\hline distXmale & 0.008 & 0.002 & 5.120 & 0.000 & 0.005 & 0.011 \\
\hline distXelderly & -0.043 & 0.002 & -23.810 & 0.000 & -0.046 & -0.039 \\
\hline distXwhite & 0.029 & 0.003 & 8.490 & 0.000 & 0.022 & 0.036 \\
\hline distXincome & 0.000 & 0.000 & -3.060 & 0.002 & 0.000 & 0.000 \\
\hline distXlengstay & 0.000 & 0.000 & 3.260 & 0.001 & 0.000 & 0.000 \\
\hline distXpctravl & 0.264 & 0.008 & 34.240 & 0.000 & 0.249 & 0.279 \\
\hline distXotherproc & 0.005 & 0.001 & 7.750 & 0.000 & 0.004 & 0.007 \\
\hline distXotherdiag & -0.008 & 0.001 & -13.900 & 0.000 & -0.009 & -0.007 \\
\hline maleXfp & -0.159 & 0.046 & -3.490 & 0.000 & -0.248 & -0.070 \\
\hline maleXteach & -0.163 & 0.028 & -5.880 & 0.000 & -0.217 & -0.109 \\
\hline maleXnursint & 0.035 & 0.005 & 7.510 & 0.000 & 0.026 & 0.044 \\
\hline maleXtech & -0.002 & 0.002 & -0.920 & 0.357 & -0.007 & 0.002 \\
\hline eldXfp & -0.021 & 0.051 & -0.420 & 0.677 & -0.121 & 0.079 \\
\hline eldXteach & -0.696 & 0.031 & -22.300 & 0.000 & -0.757 & -0.635 \\
\hline eldXnurs int & 0.083 & 0.005 & 15.590 & 0.000 & 0.073 & 0.093 \\
\hline eldXtech & -0.041 & 0.003 & -15.120 & 0.000 & -0.046 & -0.035 \\
\hline whiteXfp & 0.066 & 0.084 & 0.790 & 0.431 & -0.099 & 0.231 \\
\hline whiteXteach & 0.670 & 0.059 & 11.320 & 0.000 & 0.554 & 0.786 \\
\hline whiteXnursint & -0.105 & 0.009 & -11.440 & 0.000 & -0.124 & -0.087 \\
\hline whiteXtech & -0.007 & 0.005 & -1.470 & 0.142 & -0.016 & 0.002 \\
\hline incomXfp & 0.000 & 0.000 & -6.050 & 0.000 & 0.000 & 0.000 \\
\hline incomXteach & 0.000 & 0.000 & -16.680 & 0.000 & 0.000 & 0.000 \\
\hline incomXnursint & 0.000 & 0.000 & 7.410 & 0.000 & 0.000 & 0.000 \\
\hline incomXtech & 0.000 & 0.000 & 14.350 & 0.000 & 0.000 & 0.000 \\
\hline lengsXfp & -0.059 & 0.004 & -13.590 & 0.000 & -0.067 & -0.050 \\
\hline lengsXteach & -0.019 & 0.002 & -9.150 & 0.000 & -0.024 & -0.015 \\
\hline lengsXnursint & -0.003 & 0.000 & -10.030 & 0.000 & -0.003 & -0.002 \\
\hline lengsXtech & 0.000 & 0.000 & -1.110 & 0.267 & 0.000 & 0.000 \\
\hline pctraXfp & 0.659 & 0.203 & 3.250 & 0.001 & 0.261 & 1.057 \\
\hline pctraXteach & -0.452 & 0.129 & -3.500 & 0.000 & -0.704 & -0.199 \\
\hline pctraXnursint & 0.476 & 0.024 & 19.800 & 0.000 & 0.429 & 0.523 \\
\hline pctraXtech & 0.046 & 0.011 & 3.990 & 0.000 & 0.023 & 0.068 \\
\hline other_prXfp & -0.030 & 0.018 & -1.610 & 0.107 & -0.066 & 0.006 \\
\hline other_prXteach & -0.017 & 0.012 & -1.400 & 0.160 & -0.040 & 0.007 \\
\hline
\end{tabular}




\begin{tabular}{|c|c|c|c|c|c|c|}
\hline other_prXnursint & 0.018 & 0.002 & 9.070 & 0.000 & 0.014 & 0.022 \\
\hline other_prtech & -0.003 & 0.001 & -2.720 & 0.006 & -0.005 & -0.001 \\
\hline other_diXfp & 0.292 & 0.019 & 15.580 & 0.000 & 0.255 & 0.328 \\
\hline other_diteach & -0.105 & 0.011 & -9.950 & 0.000 & -0.126 & -0.084 \\
\hline other_diXnursint & 0.020 & 0.002 & 11.040 & 0.000 & 0.016 & 0.023 \\
\hline other_diXtech & -0.007 & 0.001 & -7.690 & 0.000 & -0.009 & -0.005 \\
\hline match_nerv & 0.510 & 0.085 & 5.970 & 0.000 & 0.343 & 0.677 \\
\hline match_resp & 0.221 & 0.144 & 1.540 & 0.124 & -0.061 & 0.503 \\
\hline match_card & 0.702 & 0.030 & 23.070 & 0.000 & 0.642 & 0.761 \\
\hline match_obst & 2.157 & 0.061 & 35.420 & 0.000 & 2.037 & 2.276 \\
\hline match_imag & 1.273 & 0.289 & 4.400 & 0.000 & 0.705 & 1.840 \\
\hline distXdiag_endo & -0.019 & 0.009 & -2.000 & 0.045 & -0.037 & 0.000 \\
\hline distXdiag_otol & -0.011 & 0.009 & -1.280 & 0.202 & -0.028 & 0.006 \\
\hline distXdiag_resp & 0.053 & 0.006 & 9.610 & 0.000 & 0.042 & 0.064 \\
\hline distXdiag_card & 0.045 & 0.003 & 15.140 & 0.000 & 0.039 & 0.051 \\
\hline distXdiag_lymp & 0.028 & 0.009 & 3.280 & 0.001 & 0.011 & 0.045 \\
\hline distXdiag_diges & 0.000 & 0.003 & 0.120 & 0.908 & -0.006 & 0.007 \\
\hline distXdiag_urin & 0.005 & 0.005 & 1.120 & 0.263 & -0.004 & 0.015 \\
\hline distXdiag_geni & 0.002 & 0.002 & 0.850 & 0.394 & -0.003 & 0.007 \\
\hline distXdiag_obst & 0.049 & 0.002 & 19.860 & 0.000 & 0.044 & 0.054 \\
\hline distXdiag_musc & 0.016 & 0.003 & 5.860 & 0.000 & 0.010 & 0.021 \\
\hline distXdiag_inte & 0.006 & 0.005 & 1.260 & 0.207 & -0.003 & 0.015 \\
\hline distXdiag_imag & 0.050 & 0.006 & 8.440 & 0.000 & 0.038 & 0.061 \\
\hline distXdiag_nerv & 0.029 & 0.004 & 6.370 & 0.000 & 0.020 & 0.037 \\
\hline
\end{tabular}


Table 1: Case Summary 1994-2005

\begin{tabular}{|c|c|c|c|c|c|}
\hline Year & Case & Winner & Primary Reason for Decision & Market Size & Government's Alleged Pre-Merger Market Concentration \\
\hline 2005 & Evanston Northwestern Health Care & FTC & $\begin{array}{l}\text { Merger substantially lessened } \\
\text { competition }\end{array}$ & $\begin{array}{l}\text { Government: } 3 \text { hospitals } \\
\text { Defendant: } 9 \text { hospitals }\end{array}$ & 10,000 \\
\hline 1999 & $\begin{array}{l}\text { Sutter } \\
\text { (California ex rel. Lockyer v. Sutter } \\
\text { Health Sys.) }\end{array}$ & Hospitals & $\begin{array}{l}\text { Insufficient evidence of a } \\
\text { relevant geographic market }\end{array}$ & $\begin{array}{l}\text { Government: } 10 \text { hospitals } \\
\text { Defendant: } 29 \text { hospitals }\end{array}$ & \\
\hline 1998 & $\begin{array}{l}\text { Poplar Bluff (Circuit) } \\
\text { (FTC v. Tenet Healthcare) }\end{array}$ & Hospitals & $\begin{array}{l}\text { FTC failed to identify a } \\
\text { relevant geographic market }\end{array}$ & $\begin{array}{l}\text { Government: } 7 \text { hospitals } \\
\text { Defendant: } 22 \text { hospitals }\end{array}$ & $2,800-4,300$ \\
\hline 1999 & $\begin{array}{l}\text { Poplar Bluff (District) } \\
\text { (FTC v. Tenet Healthcare) }\end{array}$ & FTC & $\begin{array}{l}\text { FTC's prliminary injunction } \\
\text { request was granted but later } \\
\text { reversed (see above) }\end{array}$ & See above & See above \\
\hline 1997 & $\begin{array}{l}\text { Long Island } \\
\text { (U.S. v. Long Island Jewish Med. Ctr.) }\end{array}$ & Hospitals & $\begin{array}{l}\text { DOJ failed to identify relevant } \\
\text { product and geographic market }\end{array}$ & $\begin{array}{l}\text { Government: } 5 \text {-mile radius } \\
\text { Defendant: Nassau, Queens, } \\
\text { Western Suffolk and Manhattan }\end{array}$ & $\begin{array}{l}\text { (no pre-merger info but allegations that the merging hospitals } \\
\text { would have } 100 \% \text { of the market post-merger) }\end{array}$ \\
\hline 1996 & $\begin{array}{l}\text { Grand Rapids } \\
\text { (FTC v. Butterworth Health Corp) }\end{array}$ & Hospitals & Not-for-profit merger & $\begin{array}{l}\text { Government: } 9 \text { hospitals } \\
\text { Defendant: } 9 \text { hospitals }\end{array}$ & Approx. $1,600-1,700$ \\
\hline 1995 & $\begin{array}{l}\text { Dubuque } \\
\text { (United States v. Mercy Health Servs.) }\end{array}$ & Hospitals & $\begin{array}{l}\text { DOJ failed to identify relevant } \\
\text { product and geographic market }\end{array}$ & $\begin{array}{l}\text { Government: } 3 \text { hospitals } \\
\text { Defendant: } 19 \text { hospitals }\end{array}$ & \\
\hline 1995 & $\begin{array}{l}\text { Joplin } \\
\text { (FTC v. Freeman Hosp.) }\end{array}$ & Hospitals & $\begin{array}{l}\text { FTC failed to identify a } \\
\text { relevant geographic market }\end{array}$ & $\begin{array}{l}\text { Government: } 5 \text { hospitals } \\
\text { Defendant: } 17 \text { hospitals }\end{array}$ & 1,402 \\
\hline 1994 & $\begin{array}{l}\text { Ukiah } \\
\text { (Adventist Health Sys./West) }\end{array}$ & Hospitals & $\begin{array}{l}\text { FTC failed to identify a } \\
\text { relevant geographic market }\end{array}$ & $\begin{array}{l}\text { Government: } 5 \text { hospitals } \\
\text { Defendant: } 16 \text { hospitals }\end{array}$ & $4,600(3,196$ on appeal $)$ \\
\hline
\end{tabular}


Table 2: Geographic Market Definition Methodologies in Merger Cases (1994-2005)

\begin{tabular}{|r|l|l|l|}
\hline Year & \multicolumn{1}{|c|}{ Case } & Winner & Primary Method Used for Geographic Market definition \\
\hline $\mathbf{2 0 0 5}$ & Evanston Northwestern Health Care & FTC & $\begin{array}{l}\text { Government: Managed care testimony, } \\
\text { post-merger price increases } \\
\text { Defendant: Patient flow analysis (similar to Elzinga-Hogarty), } \\
\text { travel time, physician admitting practices }\end{array}$ \\
\hline $\mathbf{1 9 9 9}$ & $\begin{array}{l}\text { Sutter } \\
\text { (California ex rel. Lockyer v. Sutter }\end{array}$ & Hospitals & $\begin{array}{l}\text { Government: Elzinga-Hogarty and Critical Loss } \\
\text { Defendant: Critical Loss (and "direct competitor test") }\end{array}$ \\
\hline $\mathbf{1 9 9 8}$ & $\begin{array}{l}\text { Poplar Bluff (Circuit) } \\
\text { (FTC v. Tenet Healthcare) }\end{array}$ & Hospitals & $\begin{array}{l}\text { Government: Elzinga-Hogarty } \\
\text { Defendant: Critical Loss }\end{array}$ \\
\hline $\mathbf{1 9 9 7}$ & $\begin{array}{l}\text { Loplar Bluff (District) } \\
\text { (U.S. v. Long Island Jewish Med. Ctr.) }\end{array}$ & Hospitals & $\begin{array}{l}\text { Government: Testimony of managed care witnesses } \\
\text { Defendant: Patient Origin data }\end{array}$ \\
\hline $\mathbf{1 9 9 6}$ & $\begin{array}{l}\text { Grand Rapids } \\
\text { (FTC v. Butterworth Health Corp) }\end{array}$ & Hospitals & $\begin{array}{l}\text { Government: Elzinga-Hogarty } \\
\text { Defendant: Elzinga-Hogarty }\end{array}$ \\
\hline $\mathbf{1 9 9 5}$ & $\begin{array}{l}\text { Dubuque } \\
\text { (United States v. Mercy Health Servs.) }\end{array}$ & Hospitals & $\begin{array}{l}\text { Government: Elzinga-Hogarty } \\
\text { Defendant: Critical Loss }\end{array}$ \\
\hline $\mathbf{1 9 9 5}$ & $\begin{array}{l}\text { Joplin } \\
\text { (FTC v. Freeman Hosp.) }\end{array}$ & $\begin{array}{l}\text { Government: Elzinga-Hogarty } \\
\text { (Adventist Health Sys./West) }\end{array}$ & Hospitals \\
\hline $\mathbf{1 9 9 4}$ & $\begin{array}{l}\text { Gefendant: Elzinga-Hogarty } \\
\text { Defendant: Elzinga-Hogarty }\end{array}$ \\
\hline
\end{tabular}


Table 3 Summary Data for the Structural Model

\begin{tabular}{|l|c|}
\hline Consumer characteristics (N=913,547) & Mean \\
Quantity & 1.24 \\
HMO & 0.50 \\
PPO & 0.31 \\
Unscheduled & 0.53 \\
Distance to chosen hospital & 11.60 \\
& \\
Hospital Characteristics $(\mathrm{N}=368)$ & \\
Price & 4681 \\
\% For Profit & $28 \%$ \\
\% Not-For-Profit & $52 \%$ \\
\% Teaching & $21 \%$ \\
Tech Index & 15.10 \\
\% System Members & $50 \%$ \\
Beds & 192 \\
Demand & 3070 \\
Own-Price Elasticity & -4.57 \\
Cross-Price Elasticity w/rspt to closest hospital & 0.60 \\
Cross-Price Elasticity w/rspt to 2nd closest hospital & 0.40 \\
Cross-Price Elasticity w/rspt to 3rd closest hospital & 0.30 \\
Cross-Price Elasticity w/rspt to 4th closest hospital & 0.21 \\
Cross-Price Elasticity w/rspt to 5th closest hospital & 0.19 \\
\hline
\end{tabular}




\begin{tabular}{|c|c|c|c|c|c|}
\hline \multicolumn{6}{|l|}{ Table 4} \\
\hline \multirow[b]{2}{*}{ Number of Hospitals in a Market } & Critical Loss & Elzinga-Hogarty & SSNIP Mkt. Def. & HSA & MSA/PMSA* \\
\hline & & & & & \\
\hline Mean & 26.75 & 22.43 & 3.78 & 54.38 & 41.83 \\
\hline std. dev & 25.63 & 20.54 & 2.06 & 56.18 & 40.62 \\
\hline Median & 16 & 13 & 3 & 16 & 18 \\
\hline Max & 89 & 78 & 14 & 130 & 100 \\
\hline Min & 2 & 1 & 2 & 1 & 2 \\
\hline \multicolumn{6}{|l|}{ Hospital HHIs (beds) } \\
\hline Mean & 1505 & 1460 & 3874 & 1031 & 1005 \\
\hline std. dev & 1511 & 1392 & 1418 & 1377 & 1070 \\
\hline Median & 875 & 1026 & 3683 & 832 & 714 \\
\hline Max & 6914 & 10000 & 8911 & 10000 & 5947 \\
\hline Min & 183 & 211 & 1054 & 118 & 158 \\
\hline \multicolumn{6}{|l|}{ Hospital System HHIs (beds) } \\
\hline Mean & 1891 & 1899 & 3989 & 1386 & 1398 \\
\hline std. dev & 1716 & 1577 & 1442 & 1500 & 1260 \\
\hline Median & 1194 & 1499 & 3814 & 1191 & 1191 \\
\hline Max & 10000 & 10000 & 8911 & 10000 & 10000 \\
\hline Min & 356 & 439 & 1244 & 327 & 366 \\
\hline
\end{tabular}

* The number of MSAs in California is 24. The number of hospitals in the sample that are located in a MSA is 312 . 


\begin{tabular}{|c|c|c|c|c|c|c|c|c|c|c|c|c|}
\hline \multirow{3}{*}{\begin{tabular}{|l} 
Table 5 \\
Market size by quartile of the number of hospitals \\
within a 25-mile radius \\
Number of Hospitals in a Market
\end{tabular}} & \multirow{2}{*}{\multicolumn{3}{|c|}{ 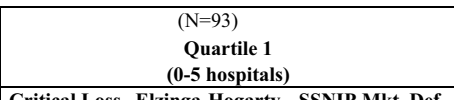 }} & \multicolumn{3}{|c|}{$\begin{array}{l}(\mathrm{N}=96) \\
\text { Quartile 2 } \\
(6-18 \text { hospitals })\end{array}$} & \multicolumn{3}{|c|}{$\begin{array}{c}\text { (N=88) } \\
\text { Quartile 3 } \\
(19-70 \text { hospitals) } \\
\end{array}$} & \multicolumn{3}{|c|}{$\begin{array}{c}(\mathrm{N}=91) \\
\text { Quartile 4 } \\
\text { (71-110 hospitals) }\end{array}$} \\
\hline & & & & \multicolumn{3}{|c|}{ Critical Loss Elzinga-Hogarty SSNIP Mkt. Def. } & \multicolumn{3}{|c|}{ Critical Loss Elzinga-Hogarty SSNIP Mkt. Def. } & \multicolumn{3}{|c|}{ 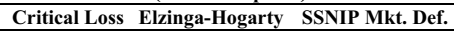 } \\
\hline & & & & & & & & & & 6547 & & \\
\hline $\begin{array}{r}\text { Mean } \\
\text { std. dev }\end{array}$ & $\begin{array}{l}5.80 \\
5.51\end{array}$ & $\begin{array}{l}7.19 \\
4.69\end{array}$ & $\begin{array}{l}2.78 \\
1.24\end{array}$ & $\begin{array}{c}10.79 \\
9.19\end{array}$ & $\begin{array}{l}9.51 \\
5.55\end{array}$ & $\begin{array}{l}2.80 \\
1.17\end{array}$ & $\begin{array}{l}26.27 \\
11.77\end{array}$ & $\begin{array}{l}23.73 \\
15.30\end{array}$ & $\begin{array}{l}3.64 \\
1.30\end{array}$ & $\begin{array}{l}65.47 \\
13.50\end{array}$ & $\begin{array}{l}50.37 \\
15.18\end{array}$ & $\begin{array}{l}5.96 \\
2.42\end{array}$ \\
\hline Median & 4 & 6 & 2 & 8 & 8 & 2 & 24 & 18 & 4 & 67 & 50 & 5 \\
\hline Max & 46 & 22 & 10 & 48 & 26 & 7 & 76 & 73 & 7 & 89 & 78 & 14 \\
\hline Min & 2 & 1 & 2 & 2 & 1 & 2 & 11 & 7 & 2 & 28 & 9 & 2 \\
\hline Unique Markets & 68 & 57 & 73 & 65 & 49 & 73 & 68 & 43 & 72 & 86 & 30 & 79 \\
\hline Difference in Market Size from SSNIP Market Def. & & & & & & & & & & & & \\
\hline Mean & 3.01 & 4.41 & - & 7.99 & 6.71 & - & 22.64 & 20.09 & - & 59.52 & 44.42 & - \\
\hline std. dev & 4.98 & 4.94 & - & 9.17 & 5.60 & - & 11.58 & 15.15 & - & 12.96 & 15.17 & - \\
\hline Median & 1 & 3 & - & 5 & 5 & - & 20 & 16 & - & 62 & 44 & - \\
\hline Max & 36 & 20 & - & 45 & 23 & - & 72 & 68 & - & 85 & 73 & - \\
\hline Min & -3 & -3 & - & -2 & -1 & - & 8 & 3 & - & 22 & 2 & - \\
\hline Hospital System HHIs (beds) & & & & & & & & & & & & \\
\hline T & 3471 & 3161 & 4694 & 2460 & 2510 & 4823 & 1065 & 1250 & 3820 & 474 & 592 & 2552 \\
\hline std. dev & 1719 & 1920 & 1053 & 1636 & 1270 & 1198 & 750 & 683 & 1441 & 61 & 205 & 675 \\
\hline Median & 3448 & 2611 & 5047 & 2243 & 2290 & 5045 & 770 & 1134 & 3372 & 468 & 545 & 2538 \\
\hline Max & 10000 & 10000 & 7381 & 10000 & 10000 & 8911 & 2769 & 2960 & 8362 & 695 & 1367 & 5006 \\
\hline Min & 524 & 745 & 1452 & 392 & 721 & 2450 & 356 & 439 & 1814 & 380 & 442 & 1244 \\
\hline \multirow{2}{*}{\begin{tabular}{|l|} 
Hospitals Operating within Guideline Thresholds \\
Premerger $\mathrm{HHI}<1500$
\end{tabular}} & & & & & & & & & & & & \\
\hline & 8 & 15 & 1 & 24 & 18 & 0 & 72 & 61 & 0 & 91 & 91 & 4 \\
\hline $1500 \leq$ Premerger $\mathrm{HHI} \leq 2500$ & 15 & 30 & 1 & 39 & 40 & 1 & 6 & 24 & 11 & 0 & 0 & 40 \\
\hline $2500<$ Premerger HHI & 64 & 48 & 91 & 33 & 38 & 95 & 10 & 3 & 77 & 0 & 0 & 47 \\
\hline Number of Hospitals within 25 miles & & & & & & & & & & & & \\
\hline Mean & & 2.40 & & & 10.71 & & & 36.15 & & & 93.10 & \\
\hline std. dev. & & 1.61 & & & 3.54 & & & 16.60 & & & 9.93 & \\
\hline
\end{tabular}




\begin{tabular}{|c|c|c|c|c|}
\hline \multirow{2}{*}{$\begin{array}{l}\text { Table } 6 \\
\text { Own Elasticity by Hospital Concentration Quartile }\end{array}$} & \multicolumn{4}{|c|}{ Own Price Elasticity } \\
\hline & Quartile 1 & Quartile 2 & Quartile 3 & Quartile 4 \\
\hline Mean & -3.55 & -4.24 & -5.05 & $\begin{array}{l}-5.48 \\
\end{array}$ \\
\hline std. dev & 1.51 & 1.78 & 1.55 & 1.66 \\
\hline Median & -3.27 & -3.88 & -4.90 & -5.27 \\
\hline $\operatorname{Max}$ & -1.01 & -1.75 & -1.67 & -2.15 \\
\hline Min & -8.87 & -11.55 & -11.33 & -10.36 \\
\hline
\end{tabular}


Table 7 Elasticity by Hospital Density Quartile

\begin{tabular}{|c|c|c|c|c|}
\hline & Quartile 1 & Quartile 2 & Quartile 3 & Quartile 4 \\
\hline \multicolumn{5}{|l|}{ Average Estimated Structural Elasticity in Critical Loss Market } \\
\hline Mean & -3.60 & -4.39 & -5.20 & -5.48 \\
\hline std. dev & 0.72 & 0.89 & 0.54 & 0.12 \\
\hline Median & -3.51 & -4.29 & -5.39 & -5.47 \\
\hline Max & -2.17 & -2.74 & -4.10 & -5.09 \\
\hline Min & -6.35 & -8.55 & -5.84 & -5.84 \\
\hline \multicolumn{5}{|l|}{ Average Estimated Structural Elasticity in Elzinga-Hogarty Market } \\
\hline Mean & -3.89 & -4.26 & -5.28 & -5.41 \\
\hline std. dev & 0.91 & 0.69 & 0.65 & 0.14 \\
\hline Median & -3.72 & -4.20 & -5.39 & -5.43 \\
\hline Max & -1.01 & -3.22 & -4.14 & -4.92 \\
\hline Min & -6.81 & -5.99 & -6.25 & -5.63 \\
\hline
\end{tabular}

\begin{tabular}{|c|c|c|c|c|}
\hline & Quartile 1 & Quartile 2 & Quartile 3 & Quartile 4 \\
\hline \multicolumn{5}{|l|}{ Average Implied Structural Elasticity in a Critical Loss Market } \\
\hline Mean & -10.10 & -13.84 & -17.27 & -18.65 \\
\hline std. dev & 7.02 & 6.86 & 6.31 & 3.58 \\
\hline Median & -8.57 & -12.54 & -15.36 & -18.53 \\
\hline Max & -2.27 & -2.74 & -7.76 & -10.51 \\
\hline Min & -30.35 & -48.13 & -36.54 & -29.02 \\
\hline \multicolumn{5}{|l|}{ Average Implied Structural Elasticity in an Elzinga-Hogarty Market } \\
\hline 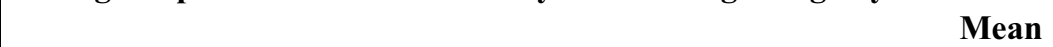 & -12.55 & -13.32 & -14.57 & -13.10 \\
\hline std. dev & 9.41 & 6.80 & 8.04 & 2.37 \\
\hline Median & -10.15 & -10.97 & -12.16 & -13.60 \\
\hline Max & -1.01 & -3.23 & -6.80 & -5.96 \\
\hline Min & -37.40 & -34.81 & -32.85 & -15.47 \\
\hline
\end{tabular}


Table 8 San Diego Hospitals

\begin{tabular}{|c|c|c|c|c|c|c|c|c|c|}
\hline Hospital & Ownership & Teach & Control & Tech Index & Beds & Price & Demand & Own Price Elasticity & \# Hosps. Within 25 Miles \\
\hline ALVARADO HOSPITAL MEDICAL CENTER & Tenet & $\mathrm{N}$ & FP & 14 & 240 & 3979 & 2213 & -4.48 & 20 \\
\hline SCRIPPS MEMORIAL HOSPITAL - CHULA VISTA & Scripps & $\mathrm{N}$ & NFP & 8 & 159 & 3931 & 1335 & -4.23 & 17 \\
\hline HARBOR VIEW HEALTH PARTNERS & Ornda & $\mathrm{N}$ & FP & 14 & 156 & 3025 & 1479 & -3.50 & 19 \\
\hline THE CORONADO HOSPITAL & Sharp & $\mathrm{N}$ & NFP & 19 & 204 & 4007 & 562 & -4.63 & 19 \\
\hline SHARP MEMORIAL HOSPITAL & Sharp & $\mathrm{Y}$ & NFP & 22 & 642 & 4238 & 15749 & -3.92 & 20 \\
\hline SCRIPPS HOSPITAL EAST COUNTY & Scripps & $\mathrm{N}$ & NFP & 14 & 162 & 3440 & 485 & -3.93 & 19 \\
\hline FALLBROOK HOSPITAL DISTRICT & & $\mathrm{N}$ & Munic & 9 & 149 & 4133 & 665 & -3.92 & 7 \\
\hline GROSSMONT HOSPITAL CORPORATION & Sharp & $\mathrm{Y}$ & NFP & 24 & 422 & 3425 & 9392 & -3.29 & 20 \\
\hline MERCY HOSPITAL & Scripps & $\mathrm{Y}$ & NFP & 16 & 416 & 4282 & 8242 & -4.30 & 19 \\
\hline MISSION BAY MEMORIAL HOSPITAL & Columbia & $\mathrm{N}$ & FP & 18 & 128 & 2219 & 613 & -2.66 & 20 \\
\hline PALOMAR POMERADO HEALTH SYSTEM (Escondido) & Palomar & $\mathrm{N}$ & Munic & 21 & 389 & 3874 & 5247 & -3.30 & 12 \\
\hline PARADISE VALLEY HOSPITAL & Adventist & $\mathrm{N}$ & NFP & 15 & 228 & 3035 & 703 & -3.55 & 18 \\
\hline SCRIPPS HEALTH - LA JOLLA & Scripps & $\mathrm{N}$ & NFP & 27 & 454 & 4211 & 10376 & -3.98 & 21 \\
\hline TRI-CITY HOSPITAL DISTRICT & & $\mathrm{N}$ & Munic & 24 & 333 & 2865 & 5242 & -2.10 & 7 \\
\hline UCSD MEDICAL CENTER & $\mathrm{UC}$ & $\mathrm{Y}$ & NFP & 23 & 359 & 5827 & 4193 & -5.99 & 19 \\
\hline VILLA VIEW COMMUNITY HOSPITAL & & $\mathrm{N}$ & NFP & 11 & 102 & 5368 & 26 & -6.18 & 19 \\
\hline COMMUNITY HOSPITAL OF CHULA VISTA & Sharp & $\mathrm{N}$ & NFP & 15 & 306 & 4383 & 2557 & -4.15 & 17 \\
\hline PALOMAR POMERADO HEALTH SYSTEM (Poway) & Palomar & $\mathrm{N}$ & Munic & 20 & 250 & 4572 & 2819 & -4.70 & 19 \\
\hline GREEN HOSPITAL OF SCRIPPS CLINIC & Scripps & $\mathrm{Y}$ & NFP & 24 & 173 & 2357 & 5202 & -2.62 & 21 \\
\hline SAN DIEGO HOSPICE CORPORATION & & $\mathrm{N}$ & NFP & 0 & 24 & 3741 & 55 & -4.33 & 19 \\
\hline UCSD LA JOLLA, THORNTON HOSPITAL & $\mathrm{UC}$ & $\mathrm{N}$ & NFP & 13 & 62 & 4523 & 1265 & -5.02 & 21 \\
\hline
\end{tabular}


Table 9

Market Definition for San Diego

\begin{tabular}{|c|c|c|c|c|c|c|}
\hline & \multicolumn{2}{|c|}{ Critical Loss Market } & \multicolumn{2}{|c|}{ Elzinga-Hogarty } & \multicolumn{2}{|c|}{ SSNIP Mkt. Def. } \\
\hline & No. of Hospitals & HHI & No. of Hospitals & HHI & No. of Hospitals & HHI \\
\hline ALVARADO HOSPITAL MEDICAL CENTER & 16 & 2769 & 14 & 2960 & 3 & 4216 \\
\hline SCRIPPS MEMORIAL HOSPITAL - CHULA VISTA & 17 & 2692 & 18 & 2228 & 2 & 5500 \\
\hline HARBOR VIEW HEALTH PARTNERS & 16 & 2696 & 18 & 2228 & 4 & 3584 \\
\hline THE CORONADO HOSPITAL & 16 & 2696 & 18 & 2228 & 2 & 5089 \\
\hline SHARP CABRILLO HOSPITAL & 17 & 2692 & 19 & 2454 & 2 & 5254 \\
\hline SHARP MEMORIAL HOSPITAL & 18 & 2709 & 19 & 2454 & 2 & 5400 \\
\hline SCRIPPS HOSPITAL EAST COUNTY & 17 & 2500 & 15 & 2861 & 2 & 5991 \\
\hline FALLBROOK HOSPITAL DISTRICT & 38 & 775 & 14 & 2242 & 3 & 4306 \\
\hline GROSSMONT HOSPITAL CORPORATION & 16 & 2769 & 14 & 2960 & 2 & 5378 \\
\hline MERCY HOSPITAL & 17 & 2692 & 18 & 2228 & 2 & 5027 \\
\hline MISSION BAY MEMORIAL HOSPITAL & 17 & 2239 & 19 & 2454 & 4 & 6914 \\
\hline PALOMAR POMERADO HEALTH SYSTEM (Escondido) & 13 & 2083 & 14 & 2200 & 3 & 5496 \\
\hline PARADISE VALLEY HOSPITAL & 17 & 2692 & 18 & 2228 & 2 & 5159 \\
\hline SCRIPPS HEALTH - LA JOLLA & 16 & 2464 & 19 & 2454 & 3 & 8362 \\
\hline TRI-CITY HOSPITAL DISTRICT & 19 & 1873 & 14 & 2033 & 2 & 5773 \\
\hline UCSD MEDICAL CENTER & 17 & 2692 & 18 & 2228 & 2 & 5027 \\
\hline VILLA VIEW COMMUNITY HOSPITAL & 16 & 2769 & 18 & 2228 & 4 & 3029 \\
\hline COMMUNITY HOSPITAL OF CHULA VISTA & 17 & 2692 & 18 & 2228 & 2 & 5500 \\
\hline PALOMAR POMERADO HEALTH SYSTEM (Poway) & 14 & 2302 & 18 & 2228 & 3 & 5143 \\
\hline GREEN HOSPITAL OF SCRIPPS CLINIC & 16 & 2464 & 19 & 2454 & 3 & 8362 \\
\hline SCRIPPS MEMORIAL HOSPITAL - ENCINITAS & 15 & 1825 & 16 & 2064 & 3 & 5003 \\
\hline SAN DIEGO HOSPICE CORPORATION & 16 & 2696 & 18 & 2228 & 3 & 4739 \\
\hline UCSD LA JOLLA, THORNTON HOSPITAL & 16 & 2464 & 19 & 2454 & 2 & 7886 \\
\hline
\end{tabular}


Table 10: Price Increases for Mergers of Independent San Diego Hospitals

\begin{tabular}{|c|c|c|c|c|}
\hline Merger (distance between hospitals in parenthesis) & & Price increase & Merger (distance between hospitals in parenthesis) & Price increase \\
\hline Mission bay \& Alvarado (9.36 miles) & $\begin{array}{r}\text { Structural Bertrand Model } \\
\text { WTP Model }\end{array}$ & $\begin{array}{l}0.28 \% \\
0.41 \%\end{array}$ & $\begin{array}{r}\text { Alvarado \& Fallbrook (43.09 miles) } \\
\text { Structural Bertrand Model } \\
\text { WTP Model }\end{array}$ & $\begin{array}{l}0.02 \% \\
0.03 \%\end{array}$ \\
\hline Mission bay \& Paradise Valley (11.14 miles) & $\begin{array}{r}\text { Structural Bertrand Model } \\
\text { WTP Model }\end{array}$ & $\begin{array}{l}0.14 \% \\
1.06 \%\end{array}$ & $\begin{array}{r}\mid \begin{array}{r}\text { Alvarado \& Tri-City (31.36 miles) } \\
\text { Structural Bertrand Model } \\
\text { WTP Model }\end{array} \\
\end{array}$ & $\begin{array}{l}0.14 \% \\
0.22 \%\end{array}$ \\
\hline Mission bay \& Harborview (6.27 miles) & $\begin{array}{r}\text { Structural Bertrand Model } \\
\text { WTP Model }\end{array}$ & $\begin{array}{l}0.39 \% \\
0.83 \% \\
\end{array}$ & \begin{tabular}{|r|} 
Alvarado \& Villa View (2.32 miles) \\
Structural Bertrand Model \\
WTP Model
\end{tabular} & $\begin{array}{l}0.04 \% \\
0.34 \% \\
\end{array}$ \\
\hline Alvarado \& Paradise Valley (6.4 miles) & $\begin{array}{r}\text { Structural Bertrand Model } \\
\text { WTP Model }\end{array}$ & $\begin{array}{l}0.43 \% \\
0.48 \%\end{array}$ & \begin{tabular}{|r|} 
Alvarado \& San Diego Hospice (6.62 miles) \\
Structural Bertrand Model \\
WTP Model
\end{tabular} & $\begin{array}{l}0.05 \% \\
0.12 \%\end{array}$ \\
\hline Alvarado \& Harborview (7.22 miles) & $\begin{array}{r}\text { Structural Bertrand Model } \\
\text { WTP Model } \\
\end{array}$ & $\begin{array}{l}0.61 \% \\
0.23 \% \\
\end{array}$ & \begin{tabular}{|r|}
$\begin{array}{r}\text { Paradise Valley \& Fallbrook (48.82 miles) } \\
\text { Structural Bertrand Model } \\
\text { WTP Model }\end{array}$ \\
\end{tabular} & $\begin{array}{l}0.00 \% \\
0.03 \% \\
\end{array}$ \\
\hline Paradise Valley \& Harborview (5.36 miles) & $\begin{array}{r}\text { Structural Bertrand Model } \\
\text { WTP Model }\end{array}$ & $\begin{array}{l}0.46 \% \\
0.67 \%\end{array}$ & $\begin{array}{r}\text { Paradise Valley \& Tri-City (36.51 miles) } \\
\text { Structural Bertrand Model } \\
\text { WTP Model }\end{array}$ & $\begin{array}{l}0.03 \% \\
0.15 \%\end{array}$ \\
\hline Mission Bay and Fallbrook (39.84 miles) & $\begin{array}{r}\text { Structural Bertrand Model } \\
\text { WTP Model }\end{array}$ & $\begin{array}{l}0.00 \% \\
0.24 \% \\
\end{array}$ & \begin{tabular}{|r|}
$\begin{array}{r}\text { Paradise Valley \& Villa View (4.23 miles) } \\
\text { Structural Bertrand Model } \\
\text { WTP Model }\end{array}$ \\
\end{tabular} & $\begin{array}{l}0.00 \% \\
1.62 \% \\
\end{array}$ \\
\hline Mission Bay and Tri-City (26.68 miles) & $\begin{array}{r}\text { Structural Bertrand Model } \\
\text { WTP Model }\end{array}$ & $\begin{array}{l}0.11 \% \\
0.75 \%\end{array}$ & \begin{tabular}{|r|} 
Paradise Valley \& San Diego Hospice (6.01 miles) \\
Structural Bertrand Model \\
WTP Model \\
\end{tabular} & $\begin{array}{l}0.04 \% \\
0.55 \%\end{array}$ \\
\hline Mission Bay and Villa View ( 8.9 miles) & $\begin{array}{r}\text { Structural Bertrand Model } \\
\text { WTP Model }\end{array}$ & $\begin{array}{l}0.00 \% \\
1.91 \% \\
\end{array}$ & \begin{tabular}{|r|} 
Harborview and Fallbrook (45.58 miles) \\
Structural Bertrand Model \\
WTP Model
\end{tabular} & $\begin{array}{l}\mathbf{0 . 0 1 \%} \\
\mathbf{0 . 0 3 \%} \\
\end{array}$ \\
\hline Mission Bay and San Diego Hospice (5.24 miles) & $\begin{array}{r}\text { Structural Bertrand Model } \\
\text { WTP Model }\end{array}$ & $\begin{array}{l}0.01 \% \\
1.46 \%\end{array}$ & \begin{tabular}{|r|} 
Harborview and Tri-City (32.70 miles) \\
Structural Bertrand Model \\
WTP Model \\
\end{tabular} & $\begin{array}{l}0.08 \% \\
0.14 \%\end{array}$ \\
\hline Fallbrook \& Tri-City (13.85 miles) & $\begin{array}{r}\text { Structural Bertrand Model } \\
\text { WTP Model } \\
\end{array}$ & $\begin{array}{l}1.57 \% \\
5.30 \% \\
\end{array}$ & \begin{tabular}{|r|} 
Harborview and Villa View (5.32 miles) \\
Structural Bertrand Model \\
WTP Model
\end{tabular} & $\begin{array}{l}0.01 \% \\
0.74 \% \\
\end{array}$ \\
\hline Fallbrook \& Villa View (44.85 miles) & $\begin{array}{r}\text { Structural Bertrand Model } \\
\text { WTP Model }\end{array}$ & $\begin{array}{l}0.00 \% \\
0.10 \%\end{array}$ & \begin{tabular}{|r|} 
Harborview and San Diego Hospice $(1.25$ miles $)$ \\
Structural Bertrand Model \\
WTP Model
\end{tabular} & $\begin{array}{l}\mathbf{0 . 0 5 \%} \\
\mathbf{0 . 3 0} \%\end{array}$ \\
\hline Villa View \& Tri-City (32.71 miles) & $\begin{array}{r}\text { Structural Bertrand Model } \\
\text { WTP Model }\end{array}$ & $\begin{array}{l}0.00 \% \\
0.11 \% \\
\end{array}$ & \begin{tabular}{|r|} 
Tri-City \& San Diego Hospice (31.5 miles) \\
Structural Bertrand Model \\
WTP Model
\end{tabular} & $\begin{array}{l}0.00 \% \\
0.05 \%\end{array}$ \\
\hline Villa View \& San Diego Hospice (5.02 miles) & $\begin{array}{r}\text { Structural Bertrand Model } \\
\text { WTP Model }\end{array}$ & $\begin{array}{l}0.00 \% \\
2.28 \%\end{array}$ & & \\
\hline
\end{tabular}


Table 11: Price Increases for Mergers of San Diego Hospital Systems

\begin{tabular}{|lr|c|}
\hline System Merger & & Price increase \\
\hline Scripps and Sharp & Structural Bertrand Model & $16.11 \%$ \\
& WTP Model & $17.48 \%$ \\
\hline Scripps and UCSD & Structural Bertrand Model & $3.48 \%$ \\
& WTP Model & $\mathbf{8 . 3 7 \%}$ \\
\hline Sharp and UCSD & Structural Bertrand Model & $3.70 \%$ \\
& WTP Model & $\mathbf{1 3 . 3 1 \%}$ \\
\hline Palomar Pomerado and Scripps & & \\
& Structural Bertrand Model & $\mathbf{5 . 4 0 \%}$ \\
& WTP Model & $\mathbf{8 . 4 6 \%}$ \\
\hline Palomar Pomerado and Tri-City & & \\
& Structural Bertrand Model & $\mathbf{6 . 1 8 \%}$ \\
& WTP Model & $\mathbf{9 . 4 3 \%}$ \\
\hline
\end{tabular}


Figure 1

Quartile 1

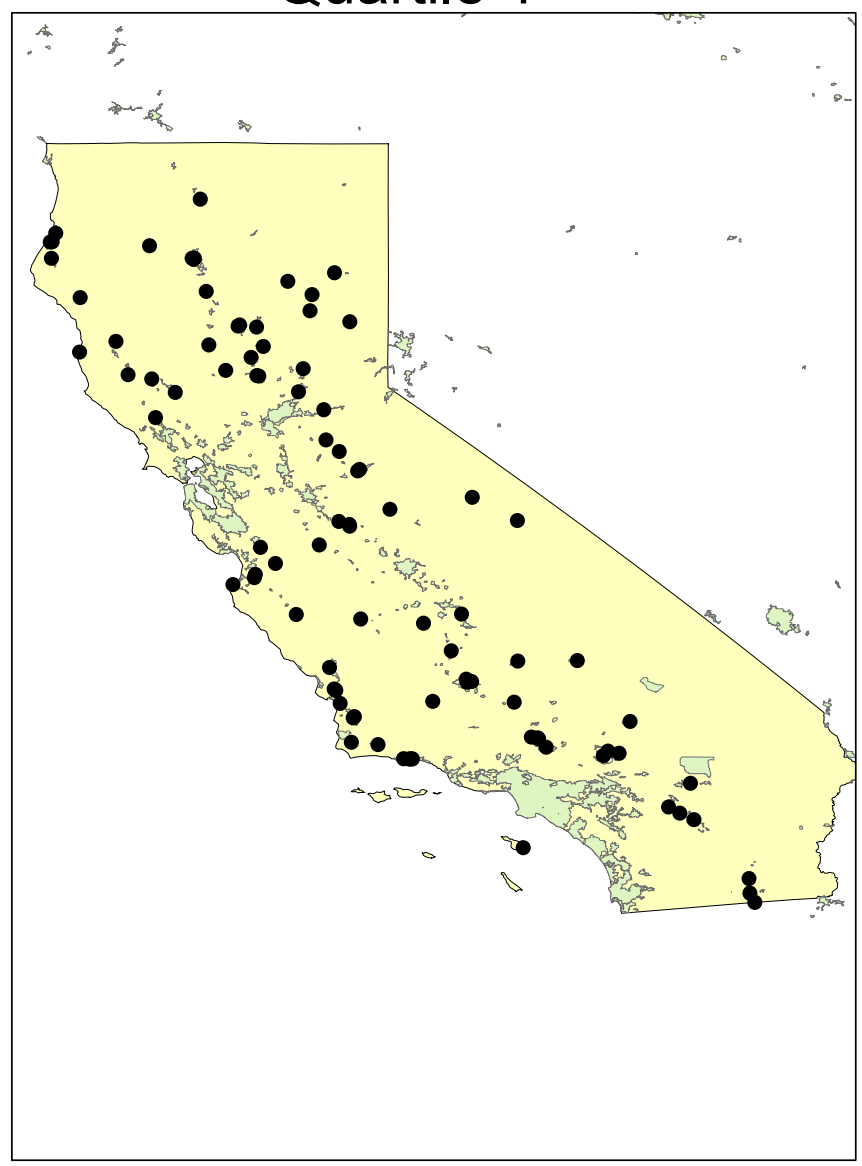

Quartile 2

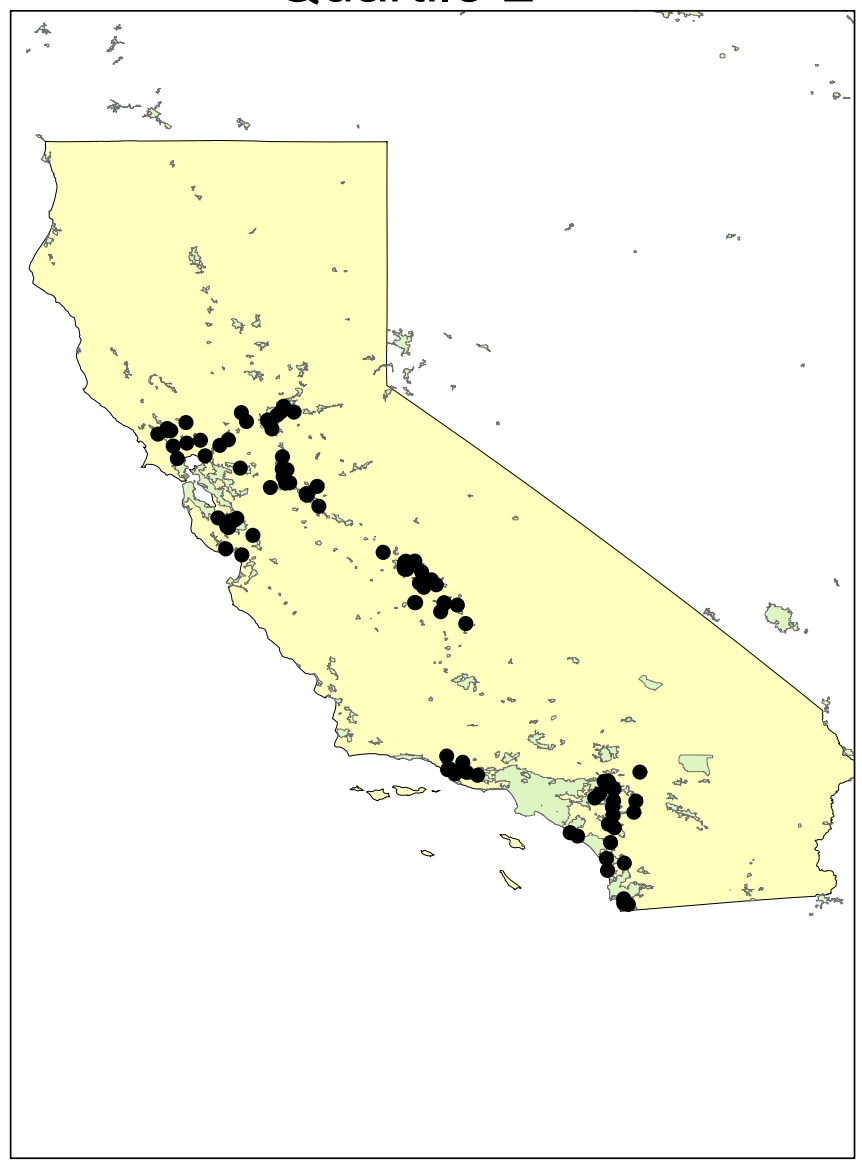

\section{Quartile 3}

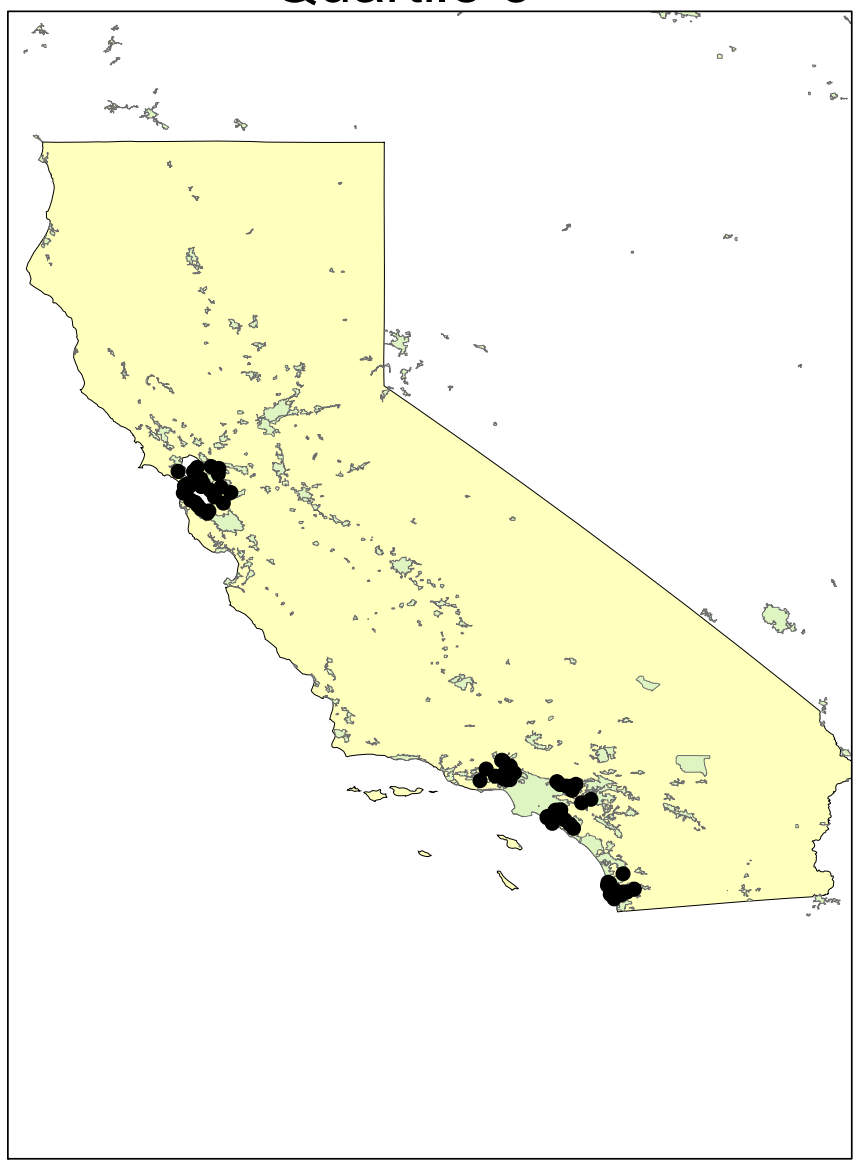

\section{Quartile 4}

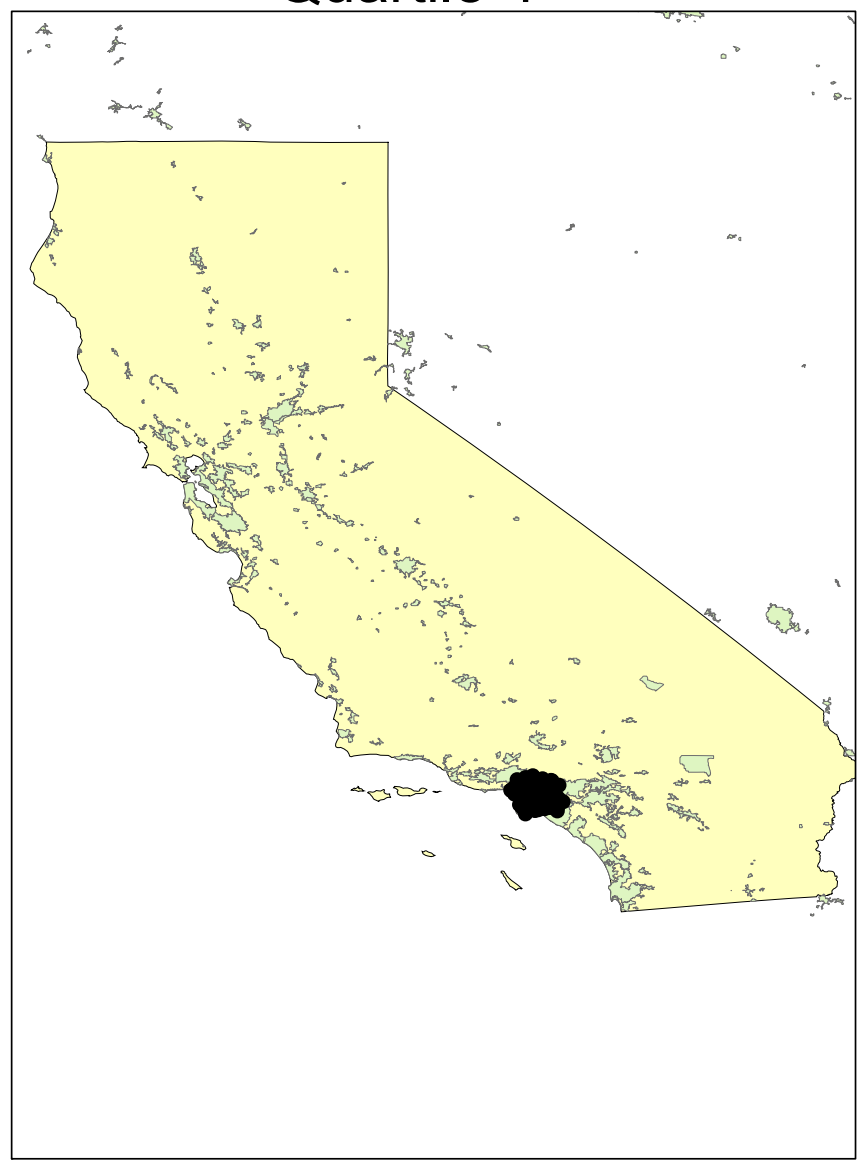


Figure 2

\section{San Diego Metro Hospitals ( $\mathrm{N}=23$ )}

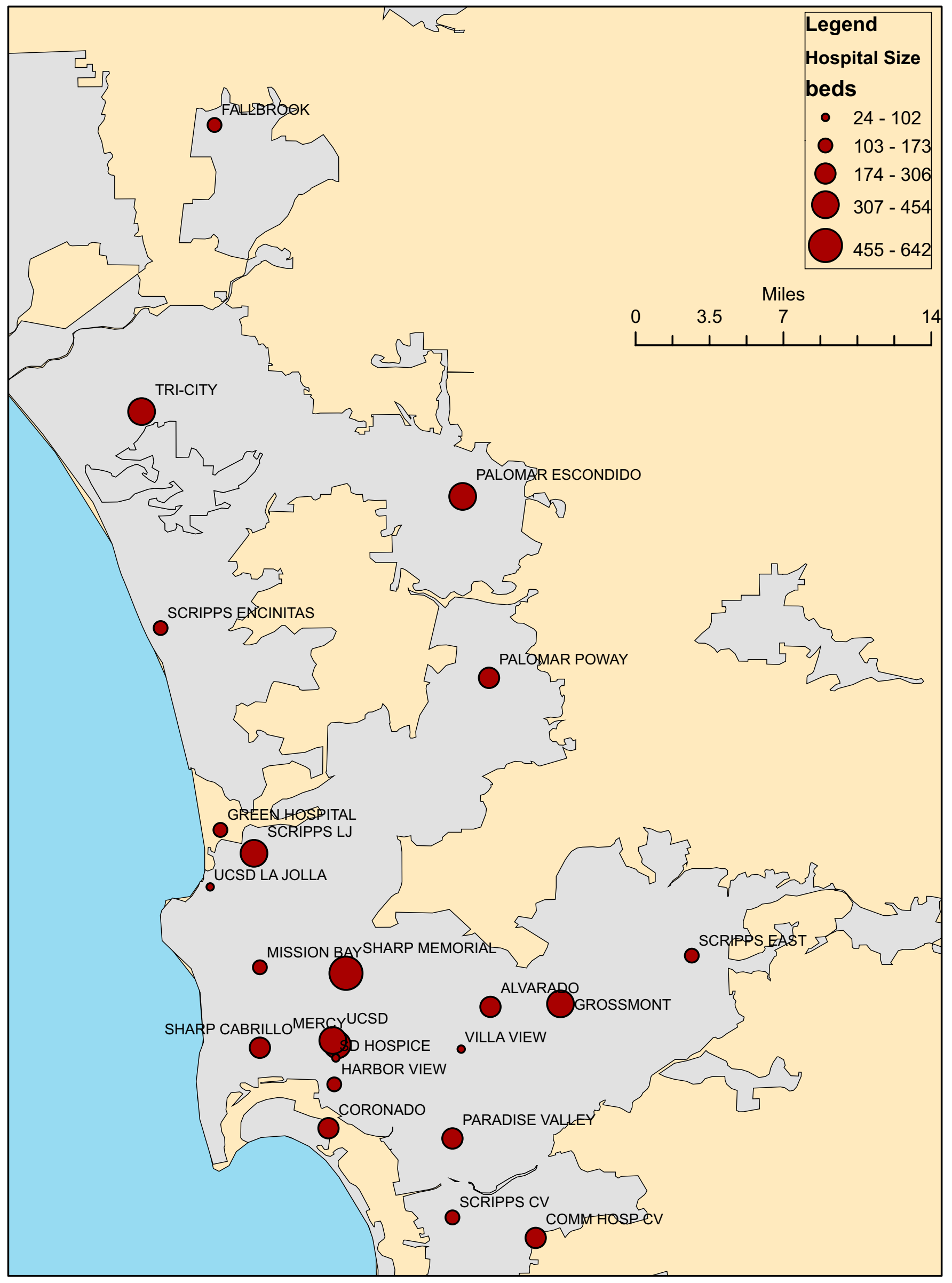




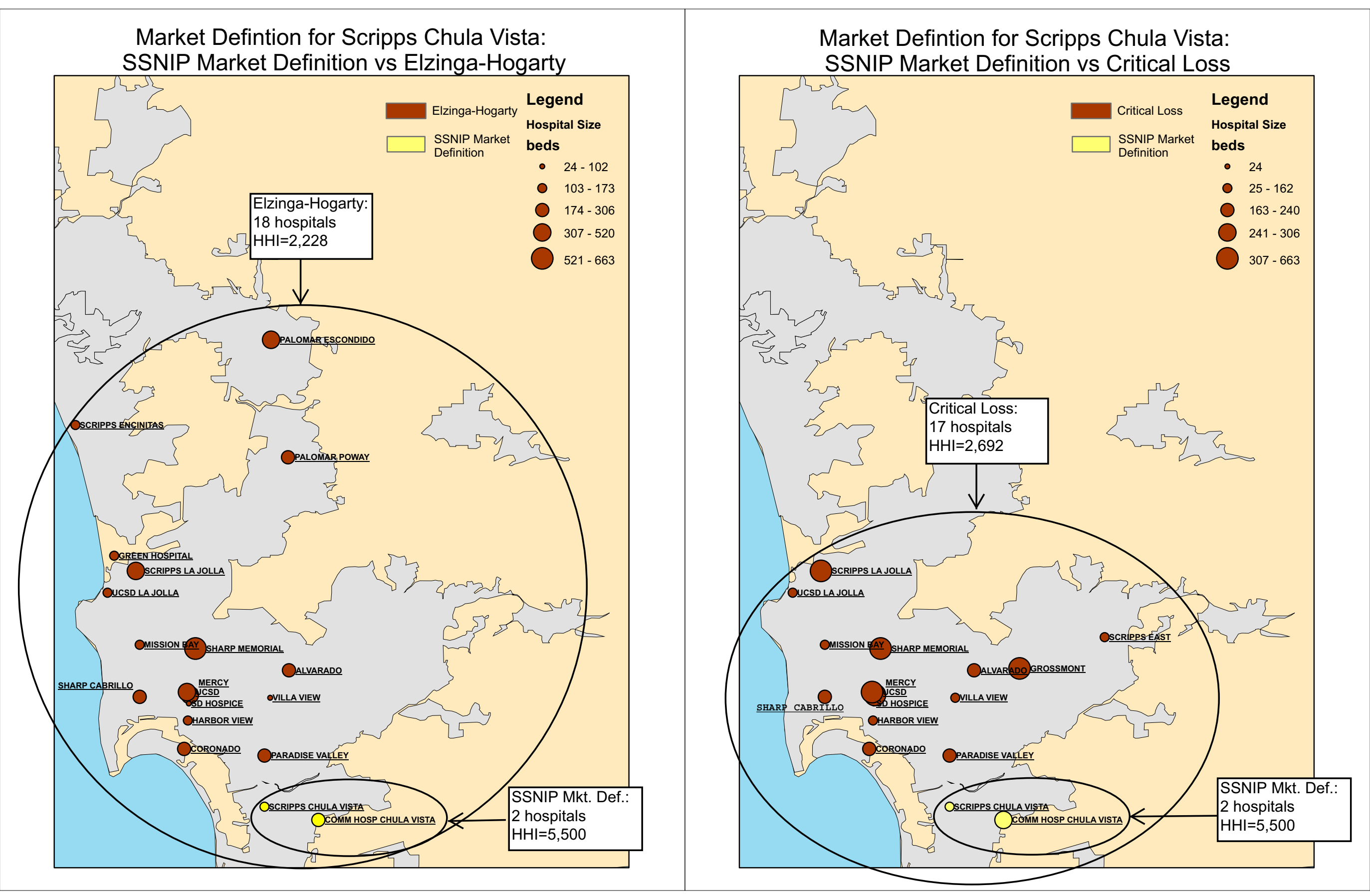

